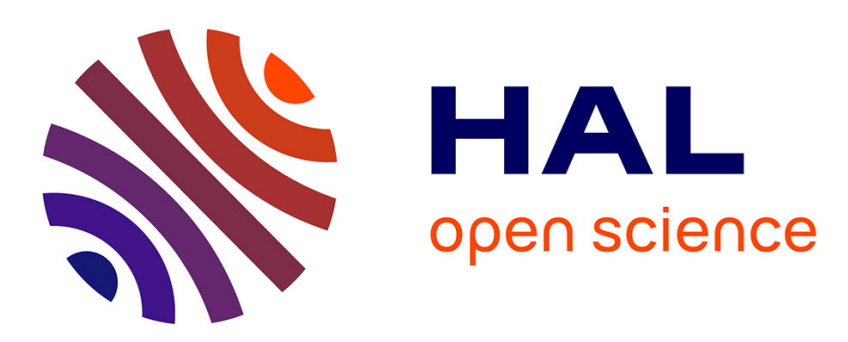

\title{
Reconstruction of subduction zone paleogeometries and quantification of upper plate material losses caused by tectonic erosion
}

Serge E. Lallemand, Philippe Schnurle, Stratis Manoussis

\section{To cite this version:}

Serge E. Lallemand, Philippe Schnurle, Stratis Manoussis. Reconstruction of subduction zone paleogeometries and quantification of upper plate material losses caused by tectonic erosion. Journal of Geophysical Research, 1992, 97 (B1), pp.217-239. 10.1029/91JB02342 . hal-01261647

\section{HAL Id: hal-01261647 \\ https://hal.science/hal-01261647}

Submitted on 27 Jan 2016

HAL is a multi-disciplinary open access archive for the deposit and dissemination of scientific research documents, whether they are published or not. The documents may come from teaching and research institutions in France or abroad, or from public or private research centers.
L'archive ouverte pluridisciplinaire HAL, est destinée au dépôt et à la diffusion de documents scientifiques de niveau recherche, publiés ou non, émanant des établissements d'enseignement et de recherche français ou étrangers, des laboratoires publics ou privés. 


\title{
Reconstruction of Subduction Zone Paleogeometries and Quantification of Upper Plate Material Losses Caused by Tectonic Erosion
}

\author{
SERGE E. LALLEMAND, PHIIIPPE SCHNURLE, AND STRATIS MANOUSSIS \\ Laboratoire de Géologie Structurale, Département de Géotectonique, Université Pierre et Marie Curie, Paris
}

\begin{abstract}
We propose in this paper an original method for quantifying the material losses at subduction zones mainly based on vertical movements of the active margins. We first test the method, using isostatic and elastic models, applying it to 15 different well-constrained convergent margins. The main conclusion is that most of them are presently close to the isostatic equilibrium. Consequently, we consider as a first hypothesis that such was also the case in the past and that erosion or accretion are natural mechanisms restoring the equilibrium in response to a perturbation. Then, we apply this model to compute the geometry of the paleoslab knowing the paleotopography of the margin. The comparison between present and past ocean margin lithospheric wedge geometries provides estimates of the removed material that constituted the initial wedge. Two cases were studied for paleoreconstructions: Japan and Peru. The results show that a considerable amount of material was removed during the Neogene along both margins. A detailed interpretation of the Neogene history of the Japan margin is proposed on the basis of our results.
\end{abstract}

\section{INTRODUCTION}

Plate boundaries and volcanic chains are the loci of important fluxes of earth material [Langmuir et al., 1987]. It remains easier to quantify material gain by intrusion of magma or sediment accretion at subduction zones rather than material loss, which is taken below geophysically observable depths in the Earth's crust or in the mantle. The reason is that we have access to volcanic rocks or accreted sediment but we have definitely lost the material that was removed by subduction/erosion. This explains why the concept of tectonic erosion (in other words, earth material transported to great depth) has taken such a long time to be generally accepted.

At a planetary scale, one may consider that the loss of material occurs mainly at subduction zones and is roughly constituted by the downgoing crust with its sedimentary cover. In counterpart, the material gain mainly originates at oceanic ridges and volcanic chains. At a subduction zone scale, this process of surficial material recycling must be refined. On one hand, studies have shown that many accretionary prisms grow through time by incorporation of mostly trench fill turbidites at the toe of the prism or underplating at some place below the lithospheric wedge. On the other hand, the consumption of some forearc margins seems to contribute to the global loss of material. We have now clear indications that this process is widely distributed around the Pacific rim and involves large amounts of material [von Huene and Scholl, 1991]: We present in this paper a method for quantifying these material losses at subduction zones.

\section{Previous STUdies}

The concept of tectonic erosion was first proposed by Rutland [1971] working on Chile and then used again for Japan [Scholl et al., 1980; Murauchi and Ludwig, 1980; von Huene et al., 1980] following a set of studies showing erosion of the upper plate by piecemeal subduction. The concept has been refined since that time owing to progress in data acquisition and processing especially off northern Japan: deep-sea drilling [e.g., von Huene et al., 1982], processing of seismic reflection

Copyright 1992 by the American Geophysical Union.

Paper number 91JB02342.

$0148-0227 / 92 / 91 \mathrm{JB}-02342 \$ 05.00$ data [e.g., von Huene and Culotta, 1989], swathmapping [e.g., Cadet et al., 1987a], magnetism [e.g., Lallemand and ChamotRooke, 1986], diving [e.g., Cadet et al., 1987b] and modeling [e.g., Lallemand and Le Pichon, 1987; von Huene and Lallemand, 1990].

Most of the arguments relative to the tectonic erosion along the Japan Trench margin come from an area intensively surveyed between latitudes $40^{\circ} \mathrm{N}$ and $41^{\circ} \mathrm{N}$. This area became a Deep Sea Drilling Project (DSDP) "reference transect" (Figure 1) used for describing the whole Japan Trench margin. Similar transects were made across the Peru Trench beginning during the Nazca Plate Project and culminating with Ocean Drilling Program (ODP). Von Huene and Lallemand [1990], after discussing the arguments for tectonic erosion, developed estimates of material removal along two transects, one off Japan $\left(40^{\circ} \mathrm{N}\right)$ and the other off Peru $\left(11^{\circ} \mathrm{S}\right)$. Their quantification included an estimate for isostatic crustal compensation related to the subsidence of both margins during the past $20 \mathrm{~m}$.y.. They estimated trench retreat rates reaching $3 \mathrm{~km} / \mathrm{m} . \mathrm{y}$. during this period and volumes of eroded masses of about 40 $\mathrm{km}^{3} / \mathrm{m} . \mathrm{y} . / \mathrm{km}$ of distance along the trench. Such rates of erosion are comparable to well-known rates of accretion. Von Huene and Scholl [1991] present an overview of both type-1 (or accretionary) and type-2 (or nonaccretionary) margins along the $44,000 \mathrm{~km}$ of subduction zones. These two types are almost equally distributed over the world: $23,000 \mathrm{~km}$ (type 1) and $21,000 \mathrm{~km}$ (type 2). An average of $20 \mathrm{~km}^{3} / \mathrm{m} . \mathrm{y} . / \mathrm{km}$ of sediment (ocean basin and trench axes deposits entering subduction zones) is tectonically accreted whereas about 32 $\mathrm{km}^{3} / \mathrm{m} . \mathrm{y} . / \mathrm{km}$ of sediment is subducted. These estimates vary from type 1 to type 2 , and the volume of material which is eroded from the upper plate during subduction is not included in but added to the $32 \mathrm{~km}^{3} / \mathrm{m}$.y./km of subducted sediment [von Huene and Scholl, 1991]. This first result of erosion rates obtained along two given transects is worth confirming using more sophisticated numerical models and is extended to the third dimension.

\section{ARGUMENTS FOR TECTONIC EROSION DEDUCED FROM THE "REFERENCE TRANSECT": NORTHERN JAPAN TRENCH}

Figure 2 summarizes the evidence that the northern Japan Trench margin has been tectonically eroded during the past 26 m.y.. The evidence is as follows. (1) At site 439 (DSDP, leg 


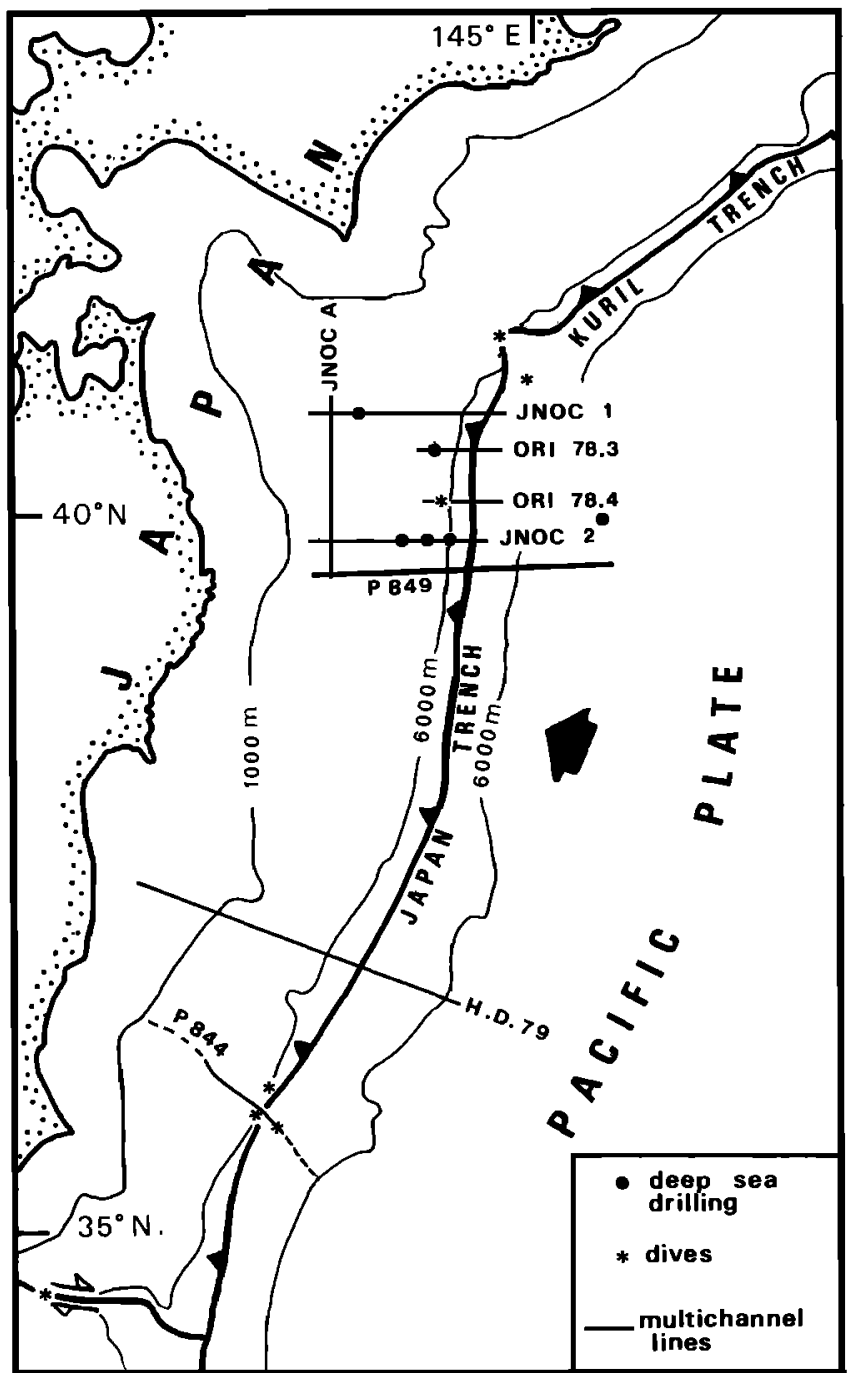

Fig. 1. Map of northeast Japan showing the Japan Trench and the southem part of the Kuril Trench. Multichannel lines, deep-sea drilling (DSDP legs 56-57 and 84) and deep KAIKO dives are plotted. Notice that most of the surveys occurred in the northemmost part of the Japan Trench near $40^{\circ} \mathrm{N}$.
57, see Figure 1 for location), the subsidence of a subaerial unconformity reached $3 \mathrm{~km}$ in $24 \mathrm{~m}$.y. on the basis of benthic foraminiferal assemblages [Keller et al., 1980]. (2) The subaerial unconformity can be followed toward the Japan Trench axis where its maximum depth, last imaged in seismic records, is $6.4 \mathrm{~km}$ [von Huene and Culotta, 1989]. These considerations yield minimum area of subsidence shown in Figure 2 by hatching. The top of this area corresponds to the paleotopography of the margin before the episode of subsidence. (3) $23.4 \pm 5.5 \mathrm{Ma}(21.4 \pm 1.0 \mathrm{Ma}$ for Yanagisawa et al. [1980]) almost in-situ dacite boulders were drilled at site 439 (DSDP) $90 \mathrm{~km}$ landward of the trench axis [Moore and Fujioka, 1980], whereas the Quaternary volcanic front is located $300 \mathrm{~km}$ landward of the trench. (4) Hornfels, derived from shales metamorphized about $29 \mathrm{Ma}$ ago, were dredged on the main scarp $10 \mathrm{~km}$ landward of the trench at a depth of 6.4 km [Takigami and Fujioka, 1989]. They may correspond to an outcrop of the basement. (5) Ocean Research Institute (ORI) 78-4 seismic line exhibits clear truncations of dipping basement strata above the décollement. (6) Little or no trench fill is imaged on seismic profiles, whereas active collapse of the Neogene sedimentary cover has been observed during KAIKO dives on the main scarp [Cadet et al., 1987b].

The well-demonstrated subsidence is the key point of this problem, and all paleo-reconstructions are based on the amount of subsidence. If we take stock of the situation since the upper Oligocene, the margin has subsided differentially from $\sim 0 \mathrm{~km}$ near the coastline to $6.4 \mathrm{~km}$ near the trench. We will also see in a next section that the margin did not subside uniformly through time. What were the mechanisms involved in this event? Langseth et al. [1981] proposed that it resulted primarily from the thermal effects associated with a start of subduction at 25-30 Ma (deduced prior to more recent plate tectonic reconstructions from the apparent absence of Paleogene volcanism). More recent work on the relative motion between Eurasian and Pacific plates shows that convergence during the Paleogene was at a rate approximately equal to Neogene convergence [e.g., Engebretson et al., 1985]. Therefore thermal effects are of considerably less importance than previously imagined by Langseth et al. [1981]. A rapid computation shows that thermal contraction is of the order of

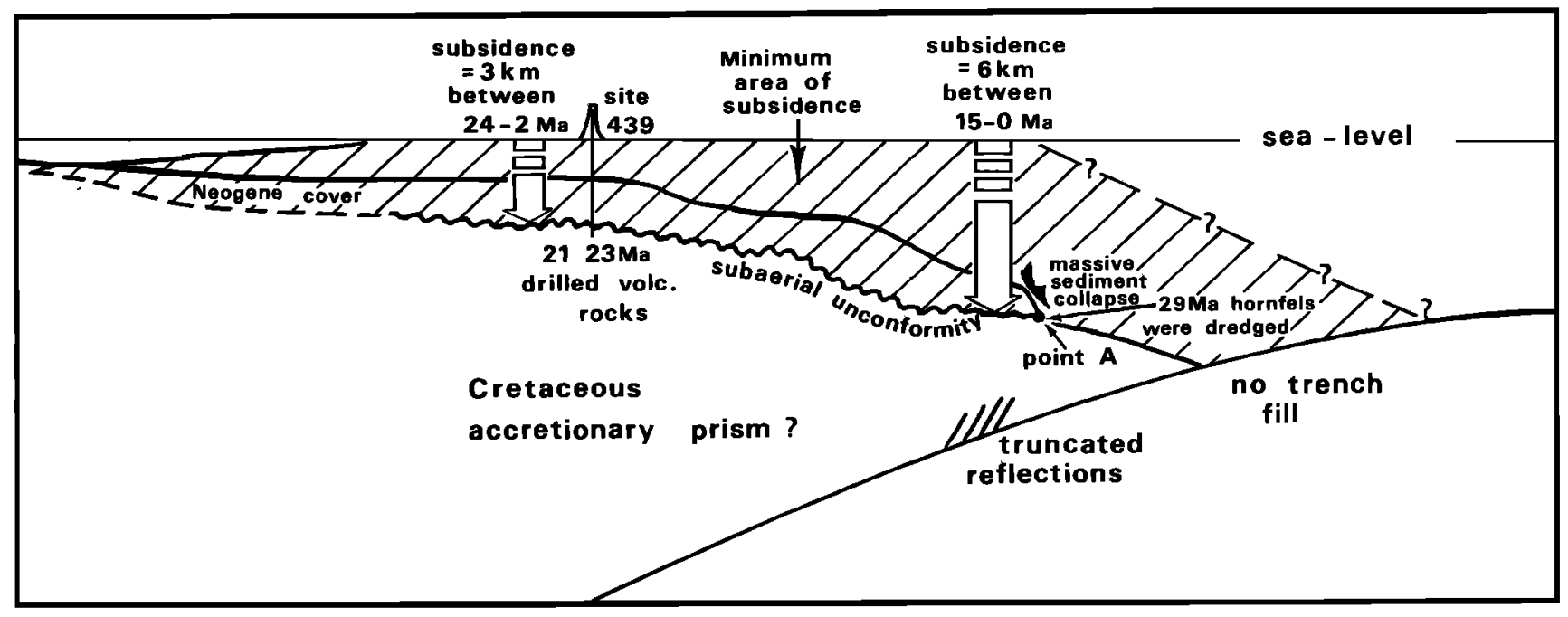

Fig. 2. Summary diagram illustrating the main arguments in favor of Neogene tectonic erosion in the Japan Trench (see explanation in the text). 
$0.3 \%$ per $\Delta \mathrm{T}=100^{\circ}$; inasmuch as we cannot envisage a temperature change of more than $100^{\circ}$ within the margin with a continuous subduction, the thermal effect should only explain a few hundred meters of subsidence. Eustatic sea level changes cannot contribute to an apparent subsidence because sea level was about $100 \mathrm{~m}$ above present one during the Miocene [ Haq et al., 1987]. Tectonic erosion is thus required in order to explain such great subsidence. In other words, a tectonic thinning and shortening of the upper plate through time seems to be the more reasonable way to explain the subsidence.

\section{The Choice of Slab Simulating Models}

The subducting plate responds in a complex manner to loading, tectonic, internal, and mantle flow forces. Furthermore, its own rheology changes drastically as the slab's thermal structure and internal stress field evolve. Loading forces are likely most important in the shallow part [Karig et $a l ., 1976]$. Deeper, the elastic thickness of the lithosphere is reduced considerably by reheating and dehydration [Pennington, 1984; Ruff and Kanamori, 1983], and plastic or viscous yielding appears [Furlong, 1982; Bodine et al., 1981]. Considerable slab bending occurs, and plate dips steepen more than $50^{\circ}$ (forming the slab bend). Large earthquakes are generally absent throughout the slab bending, indicating a largely anelastic rheology [Spence, 1987]. Deeper, the mantle flow surrounding the buoyant slab imposes a new control on the geometry [Hagger and $O^{\prime}$ Connell, 1978; Richter, 1979; Sleep, 1979]. Simulating these various effects appears rather difficult. However, because we concentrate on the shallow part of the subducting slab, we can exclude some of the less important processes involved in our simulation.

Simple elastic, viscous, visco-elastic and elasto-plastic models have been successfully developed to approximate the mechanical properties of the lithosphere in the vicinity of ocean trenches [Walcott, 1970; De Bremaecker, 1977; M C Adoo et al., 1978; Bodine et al., 1981]. Forsyth [1980] tested different mechanical models and showed that there are minor differences in modeling topographic profiles of the seaward trench slope and outer rise. Consequently, it seems reasonable to examine first the simplest models, that is to say the isostatic and the elastic models (we will consider the following terms as synonyms: elastic = nonlocal = regional, and anelastic $=$ isostatic $=$ local), and then compare them with the results obtained with more sophisticated models (P. Schnurle et al., manuscript in preparation, 1991).

Considering only the most important effects, the oceanic lithosphere can be considered a thin layer overlying a weak asthenosphere and submitted to the load of the seaward tapering lithospheric mass of the upper plates ocean margin. Thus, neglecting the tectonic forces and thermal evolution related to subduction, the removal or accretion of a significant volume of the margin should lead to an isostatic adjustment of the underthrusting slab. This compensation should be local where the ocean plate is assumed anelastic (no flexural rigidity) and regional where it is assumed elastic.

Karig et al. [1976] show that the geometry of the upper part of the subducting plate is a function of the load of the margin. When loading the assumed elastic oceanic lithosphere of the Tonga subduction zone with the volume difference between this margin and that of Aleutian margin, Karig et al. [1976] obtained a deflected Tonga subduction zone similar to the Aleutian subduction zone. It is obvious that the applications of this simple result are very attractive; this led us to reconstruct paleogeometries of subducting slabs knowing the paleotopographies of forearcs.

The first part of this study is devoted to the statement of the method and accompanying tests over 15 different wellconstrained subduction systems. Then, in the second part, we apply this method to the reconstruction of paleo-convergent margins. Our approach involves deflection of the oceanic lithosphere under the load of the margin when estimating the optimal thickness of the ancient margin wedge needed to reproduce the surface profile of its known paleotopography.

\section{HYPOTHESES AND TESTS OF THE METHOD}

Ideally, if the weight of the overriding lithospheric wedge is the main force that controls the downgoing slab position, then we are able to deduce the depth of the subducting lithosphere of a given margin by loading any of the 14 other studied margins with the difference in weight of the overriding lithospheric wedges. Comparing true and computed locations of the downgoing lithospheres provides an error bar of the method.

To look at the effects of loading the oceanic lithosphere requires a reasonable estimate of the load distribution caused by the wedge of overlying ocean margin lithosphere. In a first approximation, Karig et al. [1976] obtained good results applying a constant density of $2.7 \mathrm{~g} / \mathrm{cm}^{3}$ to the overlying crust, despite obvious overestimates of the load at the toe or the lithospheric wedge and underestimates toward the arc. To optimize densities within any margin taper, we compiled 14 density models deduced either from gravity field inversions or seismic velocity data and obtained an average curve giving the mean density versus thickness of the lithospheric wedge (Figure 3). The width of the error bars in Figure 3 reflects the great variations in rock fabric at the toe of lithospheric wedges as different as for example Tonga, where virtually no accretionary prism exists, and Nankai which is bordered by a wide accretionary prism. Using that empirical curve, we apply mean densities from $2.0 \mathrm{~g} / \mathrm{cm}^{3}$ at the toe of the prism to 3.1 $\mathrm{g} / \mathrm{cm}^{3}$ near the arc, which is more realistic.

The choice of a fixed origin is important when dealing with kinematical arguments. As no such argument is introduced in the calculation, we preferred to use as reference a vertical line crossing the same depth of the subducting slab (to simplify the calculations), located arcward of the intersection between the Moho discontinuity and the downgoing slab (Figure 4). This intersection is intuitively close to the downward limit where the load of the overlying lithospheric wedge has some effect on the bending of the slab. The origin choosen in this study is at a slab depth of $100 \mathrm{~km}$, which is commonly close to the axis of arc volcanism.

Each "system" is characterized by the position $S(x)$ and mean age $A$ (where $A$ is the mean age of the oceanic crust between the trench and the $100 \mathrm{~km}$ depth of the slab; the age of oceanic crust at $100 \mathrm{~km}$ depth being extrapolated from published reconstructions) of the underlying slab, the margin's lithospheric thickness $H(x)$ and associated weight $P(x)$ (We call "margin's lithosphere", "lithospheric wedge", or "ocean margin lithospheric wedge" the area of mantle and arc or continental crust overlying the subducting slab. Its thickness $H(x)$ is zero at trench and $100 \mathrm{~km}$ at the origin.) (Figure 4). Considering two different margins $i, j$, we apply the following process:

1. Normalization: We shift the coordinates of the system $j$ vertically to get the abyssal plain to the same depth as those of system $i$ and shift horizontally to make them coincide at the 


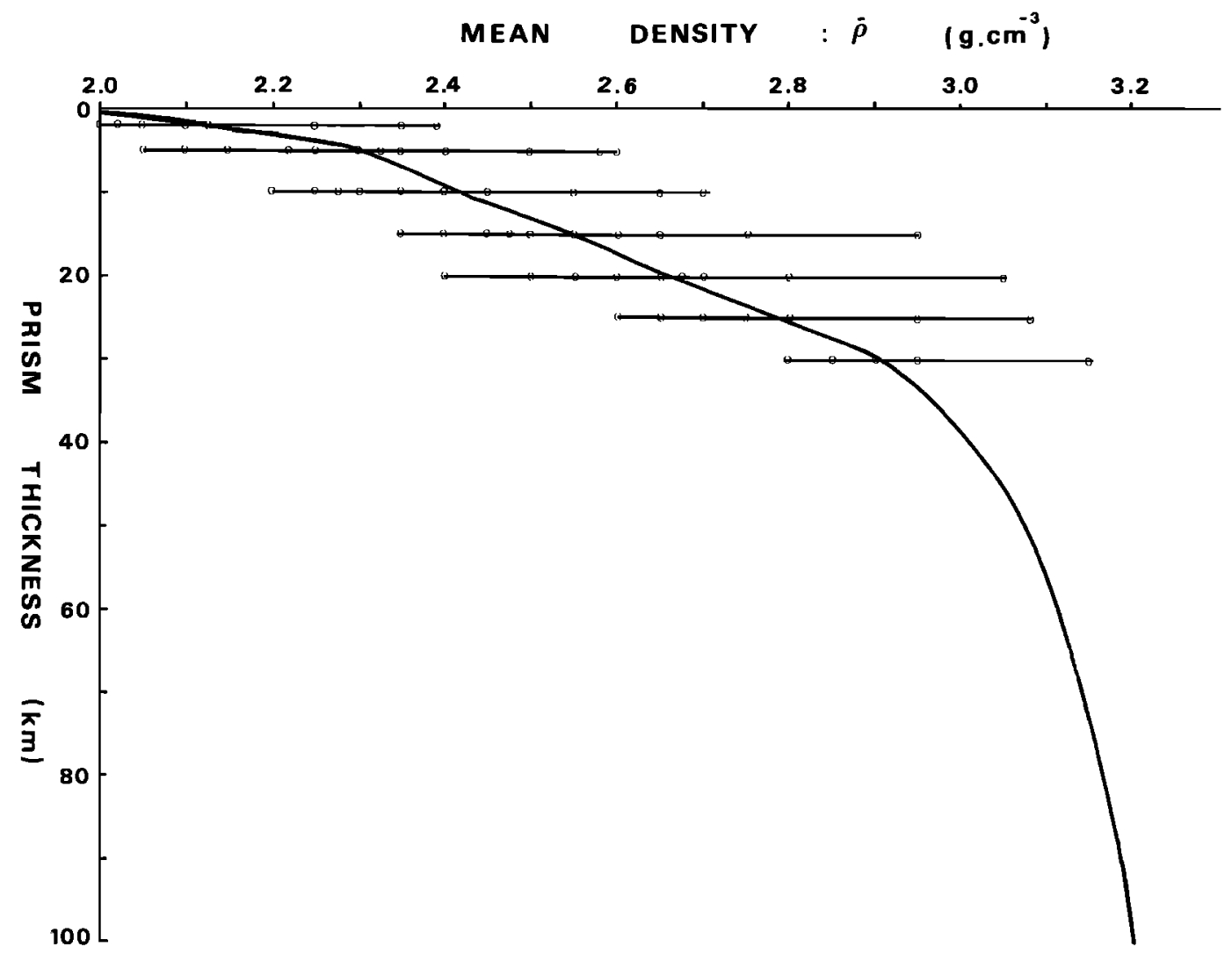

Fig. 3. Average curve showing the mean density over a lithologic lithospheric wedge column versus thickness of the column. It was deduced from 14 gravity or seismic velocity models crossing subduction zones: Nankai Trough [Murauchi et al., 1964, 1968; Yoshii et al., 1973]. Japan Trench [Yoshii, 1977; Murauchi and Ludwig, 1980; Nishizawa and Suyehiro, 1986], Kuril Trench [Nishizawe and Suyehiro, 1986; Iwasaki et al., 1989], Ryukyu Trench [Iwasaki et al., 1987], New Hebrides Trench [Collot and Fisher, 1988], Penu Trench [Jones, 1981], Sunda Trench [Kieckhefer et al., 1981], Manila Trench [Hayes and Lewis, 1984]. Tonga Trench [Missègue and Malahoff, 1982]. Small circles indicate the data; error bars are lines. The curve is extrapolated deeper than $30 \mathrm{~km}$ affecting an increasing contribution of the mantle density in the mean density.

origin $S(0)=100 \mathrm{~km}$, thus limiting the difference in weight $P_{i j}(x)=P_{i}(x)-P_{j}(x)$ (see Figure 5).

2. We then load the slab $S_{j}$ with the difference in weight $P_{i j}$ either elastically (e) using the mean rigidity $D_{i j}$, or anelastically (a) using the set of isostasy conditions (equivalent to $\left.D_{i j}=0\right)$ ).

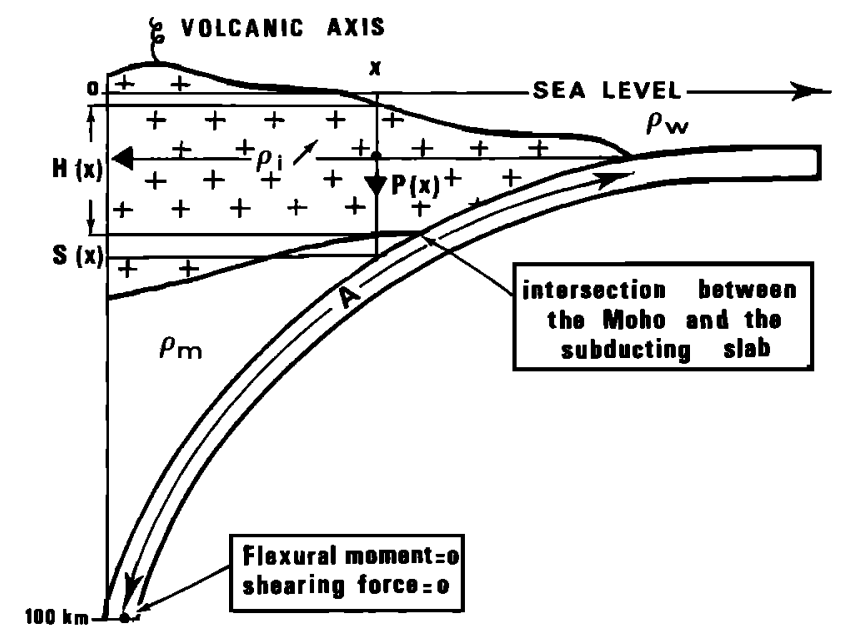

Fig. 4. Simplified diagram showing some basic parameters discussed in the text.
The previous censity distribution (Figure 3 ) is sufficient to test a local isotatic compensation when comparing two margins of given geometries $i$ and $j$. The used isostasy formulae are detailed in the Appendix. The elastic beam model is more appropriate for characterizing the nonlocal equilibrium taking into account the strength of the sinking lithosphere. Bodine et al. [1981] provide, at trench, values of the elastic thickness of the lithosphere, $T e$, as a function of its age (in million of years) : $T e=3.6 A^{1 / 2}$ (in kilometers). In a first stage, we may extend this relation to the entire slab using the mean age of the subducting plate. Then, rigidity $D$ and characteristic length $\lambda$ (inverse of the flexural parameter $\alpha$ ) are given by $D=\left(E T e^{3}\right) /\left[12\left(1-v^{2}\right)\right]$ and $\alpha^{4}=k / 4 D=1 / \lambda^{4}$ with the Young modulus $E=0.65 \times 10^{10} \mathrm{~Pa}$ and the Poisson's ratio $v=$ 0.25 . When comparing two systems $i, j$, we use the mean rigidity $D_{i j}=\left(D_{i}+D_{j}\right) / 2$.

The mathematical formulation is based on the theory of beams on elastic foundation [Hétenyi, 1946] in the case of a semi-infinite lithosphere with any load. According to the law of superposition, the general formulae for the deflection of an infinite beam $y_{\infty}(x)$ is the convolution of the load distribution $\left[P_{i j}(x)\right] / k$ and the deflection operator $A_{a_{x}}[H e ́ t e n y i, 1946$, equation 5a], $k$ being the hydrostatic restoring force. The equations are detailed in the Appendix. 


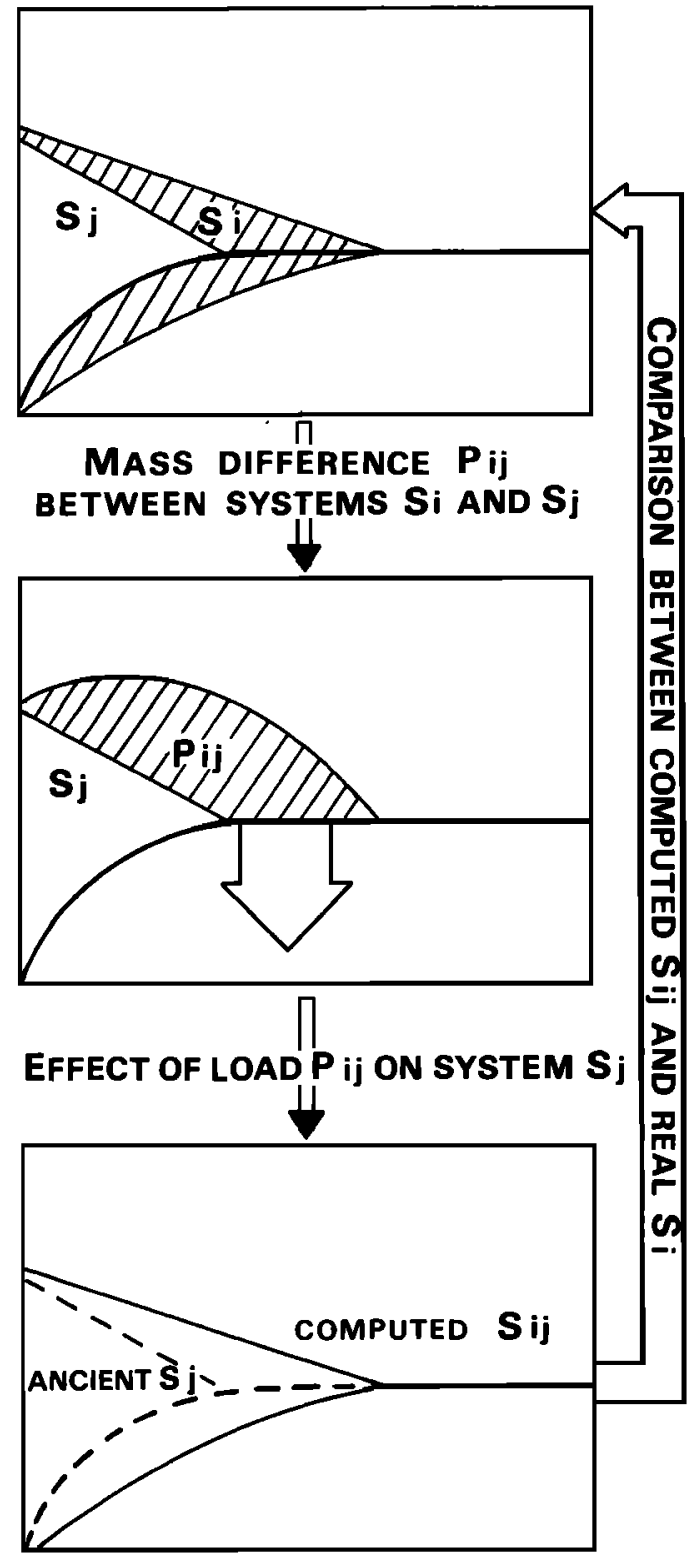

Fig. 5. Simplified diagram showing the first test procedure for the method. See explanations in the text. For clarity, we have not illustrated the nomalization procedure and the iterative process over the 13 other systems.

As the slab reheats while sinking in the warmer mantle, its elastic thickness bounded by the $450^{\circ} \mathrm{C}$ isotherm [Walcott, 1970] thins rapidly, depending mainly on the thermal state (i.e., age) and convergence rate of the incoming plate. Furthermore, plastic yielding occurs when stress inside the slab becomes important, thus reducing the elastic thickness. The easiest way to simulate the decrease in flexural rigidity, valid for every subduction system, is to use a semi-infinite beam model in which flexural moment and shearing forces are nil when the slab reaches $100 \mathrm{~km}$ depth (see Figure 4). The semi-infinite beam solutions $y(x)$ can be easily deduced from the previous infinite beam $y_{\infty}(x)$ by applying at origin the end conditioning boundary forces detailed in the appendix.

As we do not want to introduce any further process responsible for the thinning of the elastic core of the downgoing lithosphere, we propose neither calculation with an intermediate nor variable flexural parameter.

The degree of fitting between the real slab depth $S_{i}(x)$ and the computed slab depths $S_{i j}{ }_{i j}(x), S^{e}{ }_{i j}(x)$ and $S_{i j}(x)$ (where the exponents $i, e$, and $f$ refer respectively to the isostatic, elastic with infinite beam, and elastic with free edge calculations; see Appendix for further details) is used to test the validity of an elastic or isostatic adjustment of the margin in response to erosion or accretion, even when its structural configuration has been drastically changed (from context $j$ to $i$ ).

The 15 tested convergent margins are summarized in Table 1. These margin transects were selected because good geometrical constraints provided by bathymetric maps, multichannel seismic reflection and seismicity data are available for them. They also represent a large variation in age of subducting slabs, width of the lithospheric wedge, nature and location of the oceanic plate, and convergence rate.

Three transects involve the convergence of the Atlantic and Carribean plates at different latitudes along the same subduction system (Barbados and Lesser Antilles) in a zone where large structural variations take place as a function of sediment supply and subduction of ocean floor ridges through time. Five transects involve the convergence between the Pacific and North American plate (Aleutian and Kuril trenches), Indo-Australian plate (Tonga and Hikurangi trenches) and Eurasian plate (Japan Trench). Four others are located in the complex Western Pacific area. The convergent zones studied are between the Philippine Sea and Eurasian plates (Nankai Trough), the Indo-Australian plate or Eurasian plate (Java Trench), and the Solomon Sea. Four other transects are located on the eastern side of the Pacific Ocean where different plates are underthrusted below North, Central, and South American plates. They involve, from north to south, the Juan de Fuca plate (Cascadian or Oregon Trench), the Cocos plate (Middle America Trench), and the Nazca plate (Peru and Chile trenches).

Slab ages of the underthrusting lithosphere range from 7 (Oregon) to more than $130 \mathrm{Ma}$ (e.g., Tonga) at trenches, thus providing very different flexural parameters. Arc-trench distances vary from 120 (Manila) to $400 \mathrm{~km}$ (Barbados). Slab lengths range from 300 (Costa Rica) to more than $1000 \mathrm{~km}$ (e.g., Java). Shallow slab dips vary from $2^{\circ}$ (e.g., Lesser Antilles) to $15^{\circ}$ (Chile), while at depth the dips steepen between $10^{\circ}$ (Peru) and $54^{\circ}$ (Costa Rica). Convergence rates range from almost 0 (Manila) to $17 \mathrm{~cm} / \mathrm{yr}$ (Tonga), with obliquities locally reaching $60^{\circ}$ (southern Kuril).

The diversity in parameters among these margins provides a good estimate of the usefullness of the method.

\section{RESULTS AND CONSEQUENCES}

The computed slabs $s_{i j}{ }_{i j}(x), S^{e}{ }_{i j}(x)$, and $s f_{i j}(x)$ (see Appendix for further details) account for $15 \times 14=210$ arguments that favor the hypothesis of an elastic or isostatic adjustment of the margin in response to erosion or accretion, even when its structural configuration has been drastically changed (from context $j$ to $i$ ). Figure 6 is a compilation of the 15 studied convergent margins with the mean computed slabs $s_{i}{ }_{i}(x), S^{e_{i}}(x), s f_{i}(x)$ (average of the 14 others) using the elastic and isostatic models and mean absolute error versus depth $\sigma_{i}(z), \sigma_{i}^{e}(z), \sigma_{i}(z)$ of the computed slabs (see Appendix for formulae). The error is illustrated in the comer diagrams of Figure 6. 


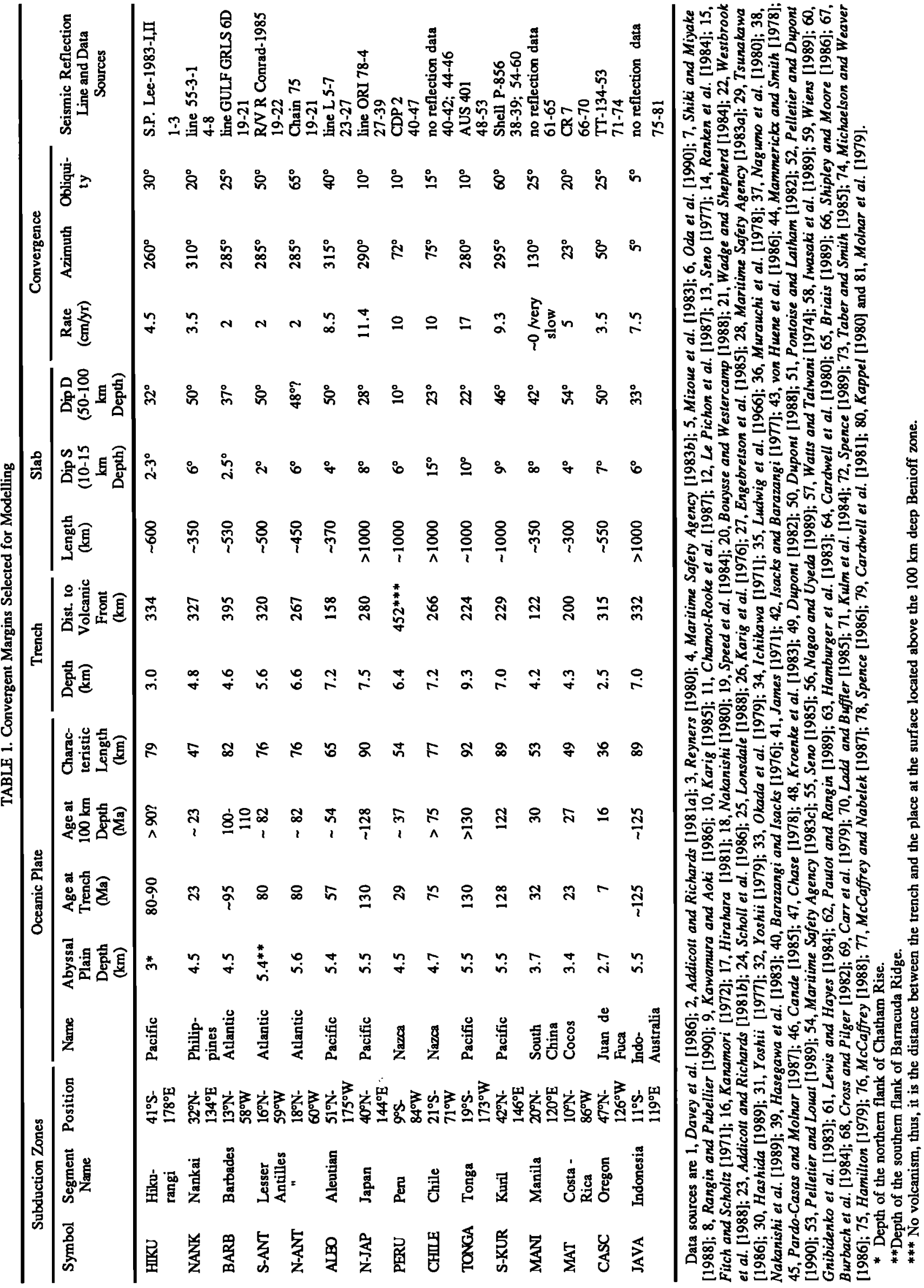



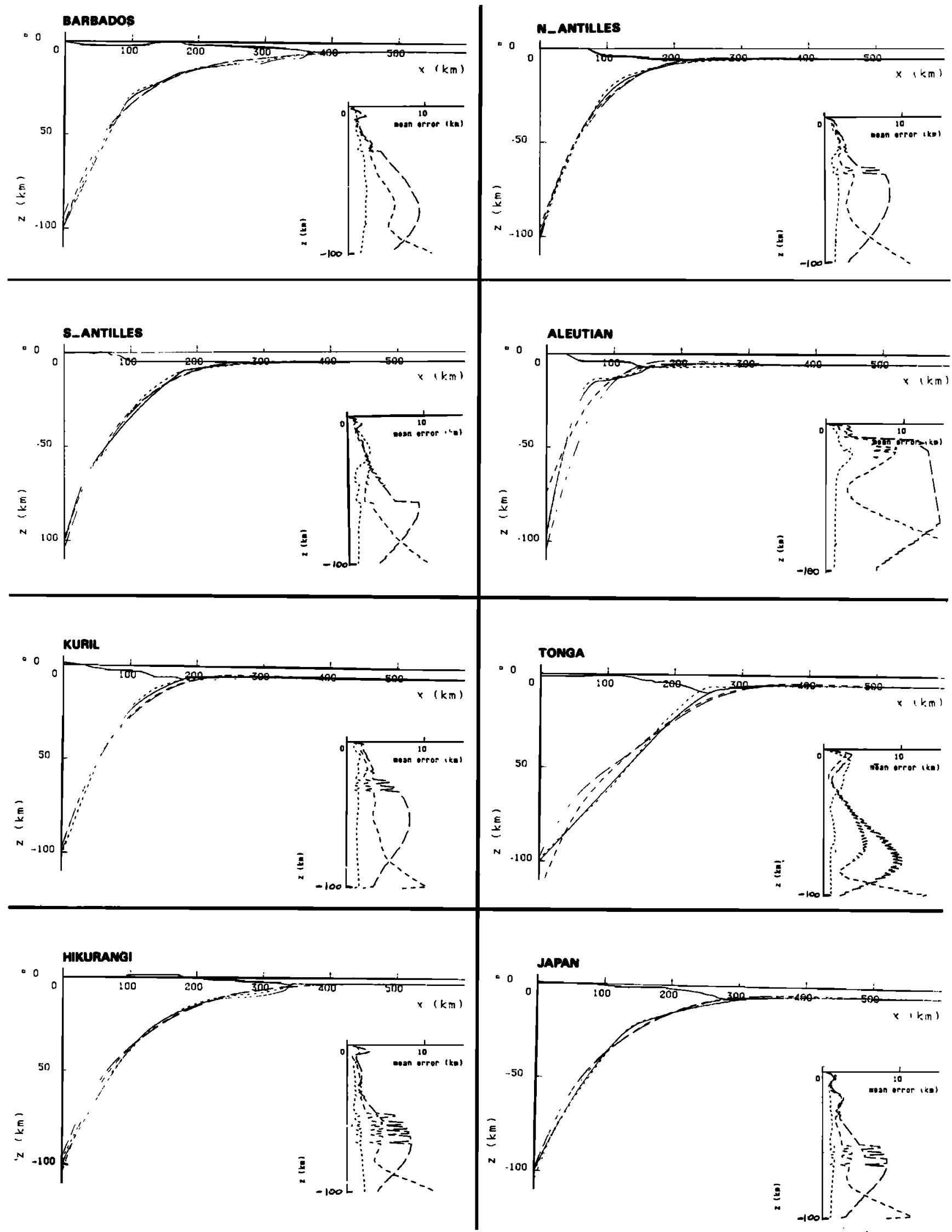

Fig. 6. The 15 margins described in Table 1 are tested by loading the slabs of the 14 others by the difference in weight between each lithospheric wedge 1-14 and those of lithospheric wedge 15 (see the procedure in Figure 5). Heavy lines represent the present geometry. Dashed lines represent the mean computed slabs (average of the 14 computed slabs) using the elastic models. Dotted lines represent the mean computed slabs using the isostatic model. The same pattern (for elastic or isostatic) is used in the mean error diagrams (error in kilometers versus depth in kilometers). The last diagram shows the mean absolute error over the 15 subduction systems. 


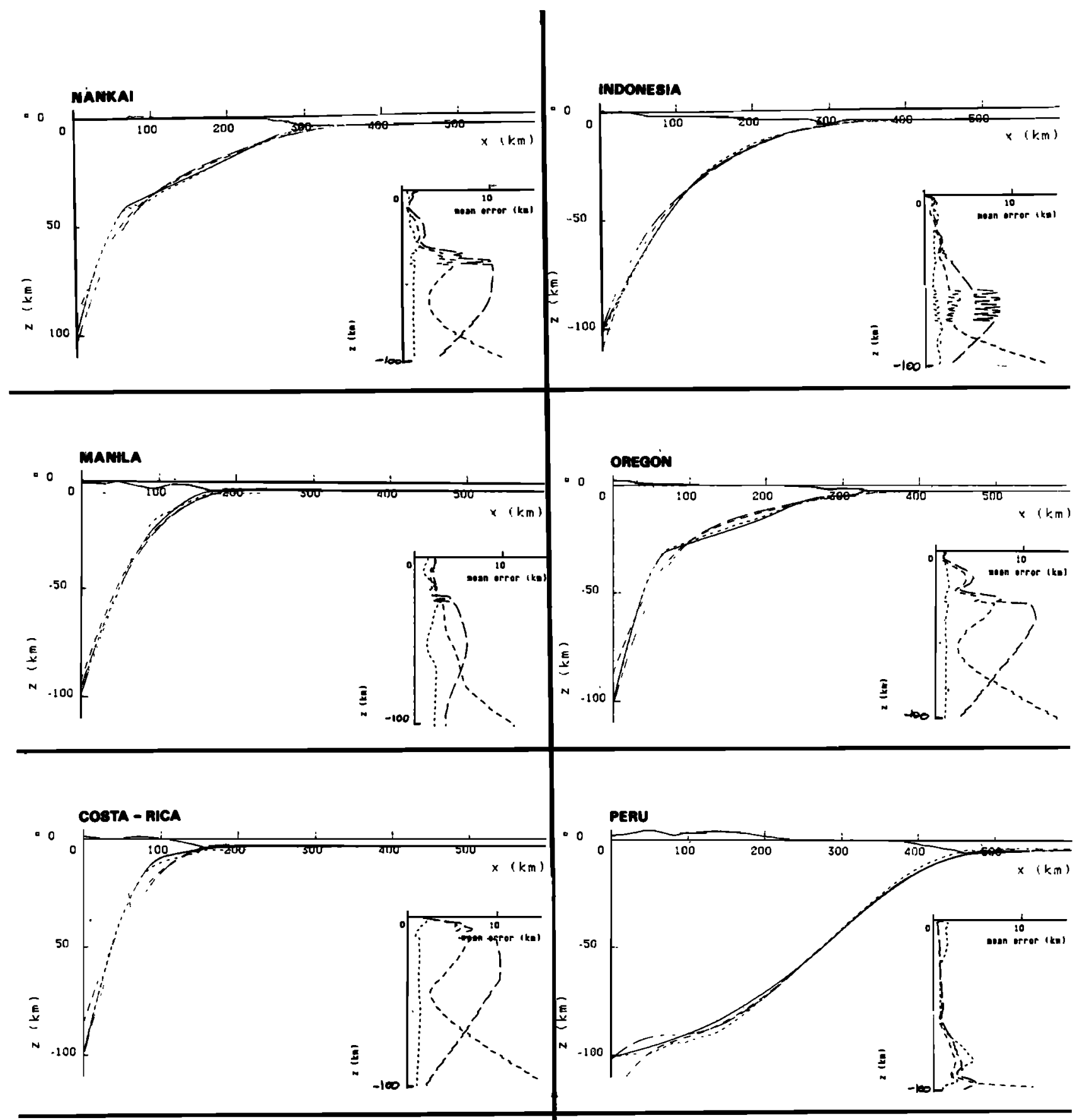

MEANABSOLUTEEERRORS OFTHE 15 SURDDUCTON SYSTEMS
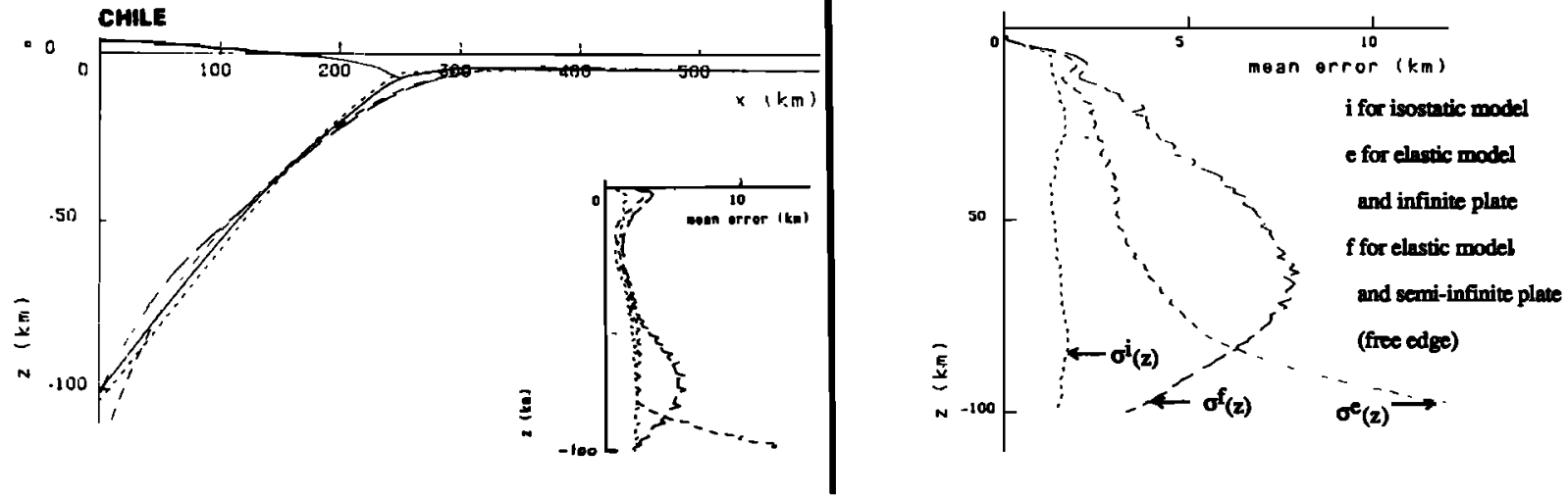

Fig. 6. (continued) 
Assuming a mean density versus thickness of the lithospheric wedge, our modeling produces results most consistent with isostatic adjustment. The isostatic adjusted slabs $S_{i j}^{i}(x)$ lie at all depth within less than $2 \mathrm{~km}$ of the observed depth $S_{i}(x)\left(\sigma_{i}^{i}(z)<2 \mathrm{~km}\right)$, whereas the elastic adjusted slabs $S^{e}{ }_{i j}(x)$ lie within $3 \mathrm{~km}$ of the observed depth only when shallower than $50 \mathrm{~km}$. The elastic adjusted slabs with a semiinfinite plate model $S f_{i j}(x)$ reduce the error at great depths compared with the infinite plate model but produce the poor fits at shallow depths. Moreover, elastic computation can account for none of the breaks in slope of Oregon, Nankai, Costa Rica, and Aleutian slabs whereas anelastic computation is not affected by strong bending. This suggests that the thinning of the elastic core occurs in the upper $50 \mathrm{~km}$ of the crust. The seaward bulge is naturally absent in the anelastic computation, whereas elastic adjusted slabs approximately account for it. Inasmuch as the basic hypothesis was to relate the slab's geometry to the lithospheric load of the margin, we are only interested in the upper part of the system (less than 30 $\mathrm{km}$ deep), and thus both modelings are satisfying. The error is mostly due to poorly constrained densities and to the simple rheology used to model the lithosphere. Therefore our models might be recomputed with a thick slab and more precise rheology to check for improvement.

However, it is clear that the various tectonic forces (slab pull, ridge push, mantle flow, and so on) neglected in our model are producing variation in observed slab geometries. The stress induced by the tectonic forces is released through removal or accretion of amounts of material within the limits of the error bars ( 2 to $3 \mathrm{~km}$ ), but its effect is mainly to perturb the isostatic equilibrium. The good results of the static approach suggest that variations instead of present magnitude of tectonic parameters are producing evolution in shape. Thus a direct modeling of the subduction geometry should take into account the margin's whole tectonic history, which is almost impossible to realize.

The "perturbative approach" should be more fruitful, and therefore we feel confident in our paleo-reconstructions.

\section{APPLication to THE REConstruction OF PAST GeOMETRIES}

When searching for the position of a paleoslab at the time of reconstruction, $T$, we shall invert the set of equations of isostasy ((1), (2), (3)), the present geometry being the reference state. Our basic hypothesis is that each modern subduction zone is more or less isostatically equilibrated and thus was also in equilibrium at the time of any past reconstruction. We thus compare instantaneous images of a convergent margin at different periods. This inversion becomes rather tedious because equation (1) becomes nonlinear (quadratic in $\mathrm{Hi}$ ) when assuming (3). The convergence of iterative results is very uncertain near the arc where the densities become close to the mantle density (especially when the difference between the past and present topographies is great). Therefore we use an elastic iterative scheme (Figure 7) to solve the problem. We also test lower rigidities for the oceanic crust accounting artificially for the downward thinning of its elastic core.

In the first iteration, we deflect the present corrected slab (slab position is corrected vertically for the subsidence generated by the load of sediment that has accumulated since time $T$ ) under the minimum load necessary to account for the

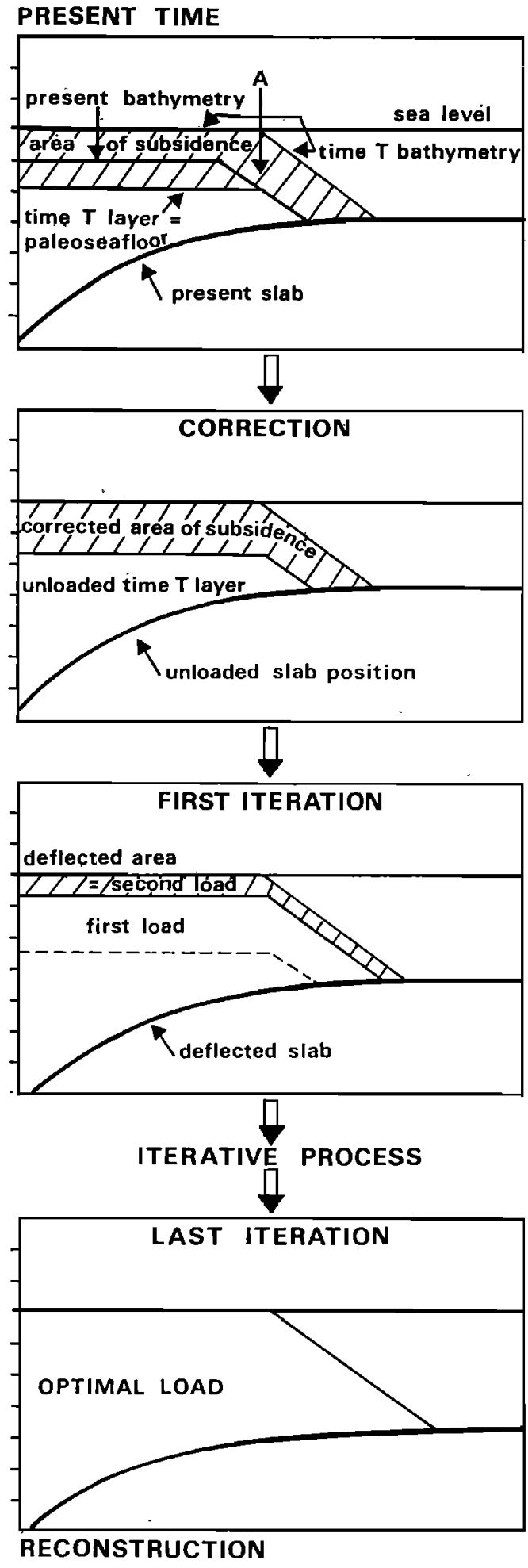

Fig. 7. Diagram showing the preliminary corrections applied before running the first iteration and the iterative process. In the first iteration, we deflect the present corrected slab under the minimum load necessary to account for the assumed (corrected) area of subsidenice (the present geometry is considered as the reference state). In the second iteration, we reload the previous deflected slab with the sediment that filled the deflected area because all the lithospheric wedge-slab system subsided by the same amount and the newly created topography does not coincide with the paleotopography. Each weight is given by the difference in weight between each lithospheric wedge in order to affect the right mean density to the new load. This operation is iterated until the weight of the infill becomes negligible, thus attesting that the equilibrium is reached. 
assumed (corrected) area of subsidence (We call "area of subsidence" the area between the paleotopography at time $T$ and the present depth to this buried and subsided paleosurface, this paleosurface is corrected from its subsidence created by the load of sediment that has accumulated above it since time $T$ ) (the present geometry is considered as the reference state; see Figure 7). In the second iteration, we reload the previous deflected slab with the sediment that filled the deflected area because all the lithospheric wedge-slab system subsided by the same amount and the newly created topography does not coincide with the paleotopography. Each weight is given by the difference in weight between each lithospheric wedge, in order to affect the right mean density to the new load. This operation is iterated until the weight of the infill becomes negligible, thus attesting that the equilibrium is reached.

Let now consider two keypoints acting on the results. They are the choice of the paleotopography profile and the deep paleoslab geometry.

The paleotopography can be constrained, using deep-sea drilling and seismic reflection results, up to a certain point (A on Figure 7) located landward of the present trench. This point $A$ is the seawardmost place where we can identify the paleoseafloor at the time of its burial by the "time $T$ layer", which is the layer deposited at the time of reconstruction. To simplify, let us consider that paleotopography was subaerial until point $A$. How can we extend the paleotopography profile seaward of point $A$, inasmuch as there are no direct indicators? One possibility minimizes the subsidence area and thus assumes an overcritical slope (dipping $5^{\circ}$ or more) starting directly from point $A$ to the oceanic plate. Another possibility tests different slopes dipping from $1^{\circ}$ to $5^{\circ}$ and chooses those which give the most credible profile of the computed slab. A different approach postulates that the distance between the present trench and volcanic arc is constant through time and thus the paleotrench location could be deduced from the paleovolcanic arc location. All these possibilities are tested, and we use those that minimize the area of eroded continental margin material.

Inasmuch as we chose the most conservative method (eroded surface is minimum), we ran the program using an infinite plate model. However, whatever the subsidence area chosen, the new computed slab geometry will be more or less deflected under the load and consequently different from a normal slab profile with a downward increase of the subduction angle. When compared with present slab geometries, this circumstance seems unrealistic. How can we optimize the slab shape deep beneath the margin? One way prevents any downward decrease of the subduction angle by substituting an ideal slab shape for the unrealistic computed one. This method can provide credible geometries, but it is not based on well-constrained physics. Another way, if we know the location of the paleo-volcanic arc, is to assume that the paleoslab descended $100 \pm 20 \mathrm{~km}$ below the paleo-arc, and then extrapolate an optimal curvature of the slab starting from the point where the subduction angle decreases and crosses the $100 \mathrm{~km}$ depth under the paleovolcanic arc. Both computation tricks modify the isostatic equilibrium between arc and oceanic lithospheres and thus cause a deviation from our method, which is supposed to maintain isostatic equilibrium (starting hypothesis).

An elegant method would be, during the iterative process, to allow the deeper parts of the slab to move perpendicular to the slab face as a free edge (semi-infinite plate model, the same used for preliminary tests). This produces large lateral variations (or downward deflections) in the deeper parts, and the final computed slab appears to be deduced from the present slab by a landward migration. The removal is thus considerably increased. Is it realistic? We think that all these ways of computation have to be tested case by case and then criticized because the behavior of a $100 \mathrm{~km}$ deep slab results from several conditions like the slab length or surrounding mantle flow.

\section{The Example of the Japan Trench}

As was described earlier, the Japan Trench is a "test area" for reconstructive computations because a wealth of controlling information exists. Furthermore, minimum estimates have been proposed by von Huene and Lallemand [1990] that can be compared to these more comprehensive estimates.

Rather than use a single transect around $40^{\circ} \mathrm{N}$, we adopt a more spatial and temporal approach, because lateral variations in margin evolution have occurred. This approach allows us to present a pseudo-three-dimensional view of the evolving Japan Trench margin since upper Oligocene time.

Four transects have been selected because of their spatial distribution and the availability of multichannel data along them. From north to south, they are (see Figure 1) 1, transect at $40^{\circ} 40^{\prime} \mathrm{N}$ using line JNOC 1 [Nasu et al., 1980] which crosses DSDP holes $438-439$ that provide a good subsidence history; 2, transect at $39^{\circ} 40^{\prime} \mathrm{N}$ using lines Japan National Oil Corporation (JNOC) 2 [Nasu et al., 1980] and Shell-P 849 [Lehner et al., 1983] (this last line has been reprocessed by $\mathbf{R}$. von Huene [von Huene and Lallemand, 1990; R. von Huene, personal communication, 1990]); 3, transect between $36^{\circ} 20^{\prime} \mathrm{N}$ and $37^{\circ} 40 \mathrm{~N}$ based on line H.D. 79 [Sakurai et al., 1981]; and 4 , transect between $35^{\circ} 20^{\prime} \mathrm{N}$ and $36^{\circ} 20^{\prime} \mathrm{N}$ using line Shell-P 844, which has been partly processed and published [ [Lallemand et al., 1989].

The common observation along all these transects is the presence of an erosional unconformity cut near sea level in late Paleogene time at site 439 of DSDP [von Huene et al., 1982]. The oldest sediments onlapping this subaerial unconformity have been dated around $26 \mathrm{Ma}$. A detailed analysis of seismic reflection data, coupled with the DSDP results in the northem part of Japan Trench margin, allowed R. von Huene (personal communication, 1990) to date overlying reflection horizons and identify where these layers onlap; and then seal the unconformity at $26 \mathrm{Ma}, 23 \mathrm{Ma}$, and $16 \mathrm{Ma}$. Thus, for the northern Japan Trench (two lines), we are able to reconstruct structural images of the Japanese subduction zone at these periods. Unfortunately, processing of seismic data in the southern part (transects 3 and 4) was insufficient to identify time-specific horizons, and we assume that the clearly imaged unconformity is the same age and origin as to the northern. The comparison of the four reconstructed transects at $26 \mathrm{Ma}$ provides a unique reconstructed perspective view of the late Paleogene Japan margin.

The tests of different ways of processing for reconstruction are run only for JNOC 1 transect at $26 \mathrm{Ma}$ to show how the change of one parameter can modify the reconstruction, and then the most conservative one is used for the other transects and times of reconstruction.

Figure $8 a$ shows the northernmost transect at $26 \mathrm{Ma}$ using the elastic model first for an infinite plate with a paleoslope dipping $5^{\circ}$ seaward and a flexural rigidity for the oceanic plate being the mean flexural rigidity $\left(\alpha=0.0121 \mathrm{~km}^{-1} ; \lambda=82.2\right.$ $\mathrm{km} ; \mathrm{Te}=34.5 \mathrm{~km})$ between present configuration $(130 \mathrm{Ma}$ under the prism which implies $\alpha=0.0109 \mathrm{~km}^{-1} ; \lambda=91.7 \mathrm{~km}$; 
JNOC1 (26MY)
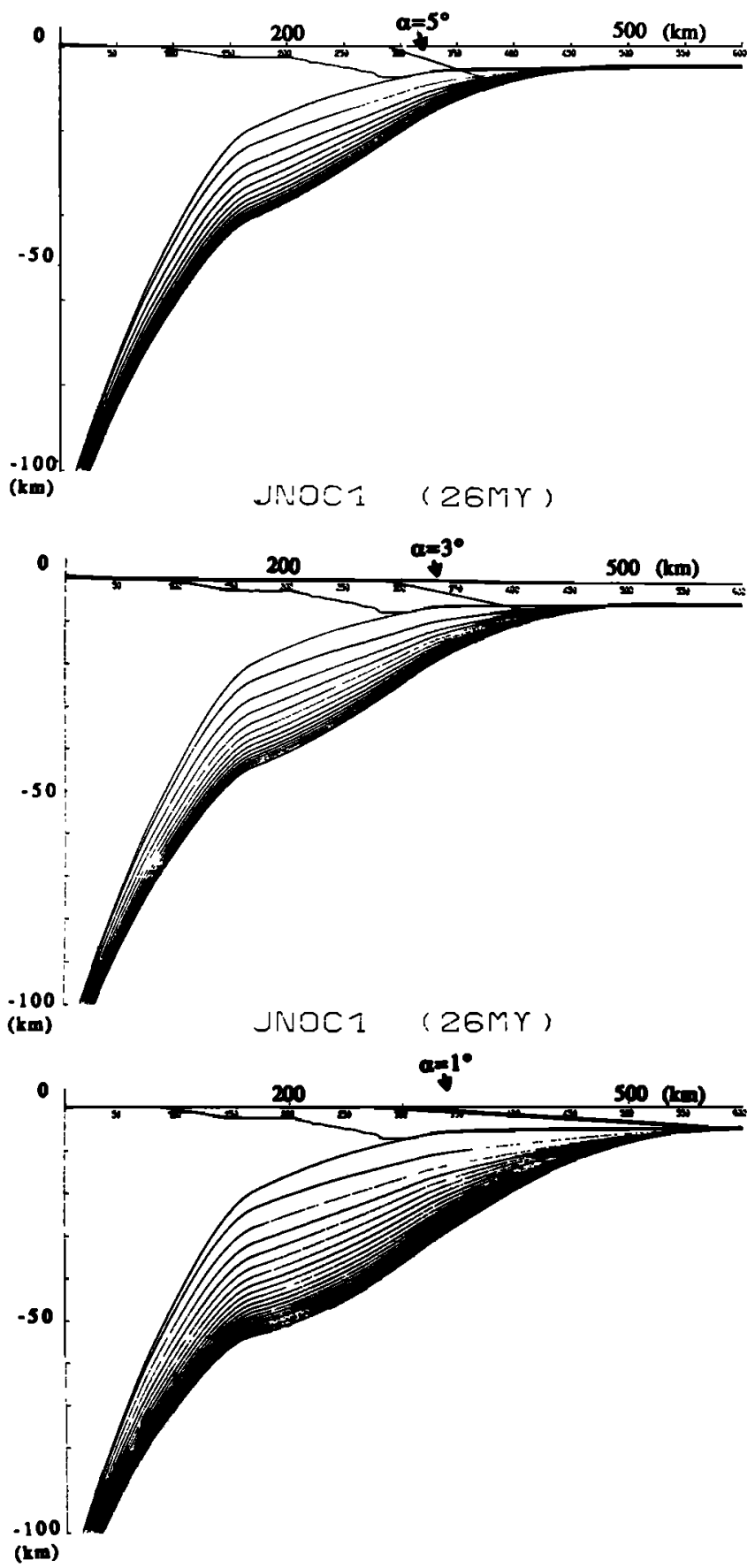

JivOC1 (26MY)
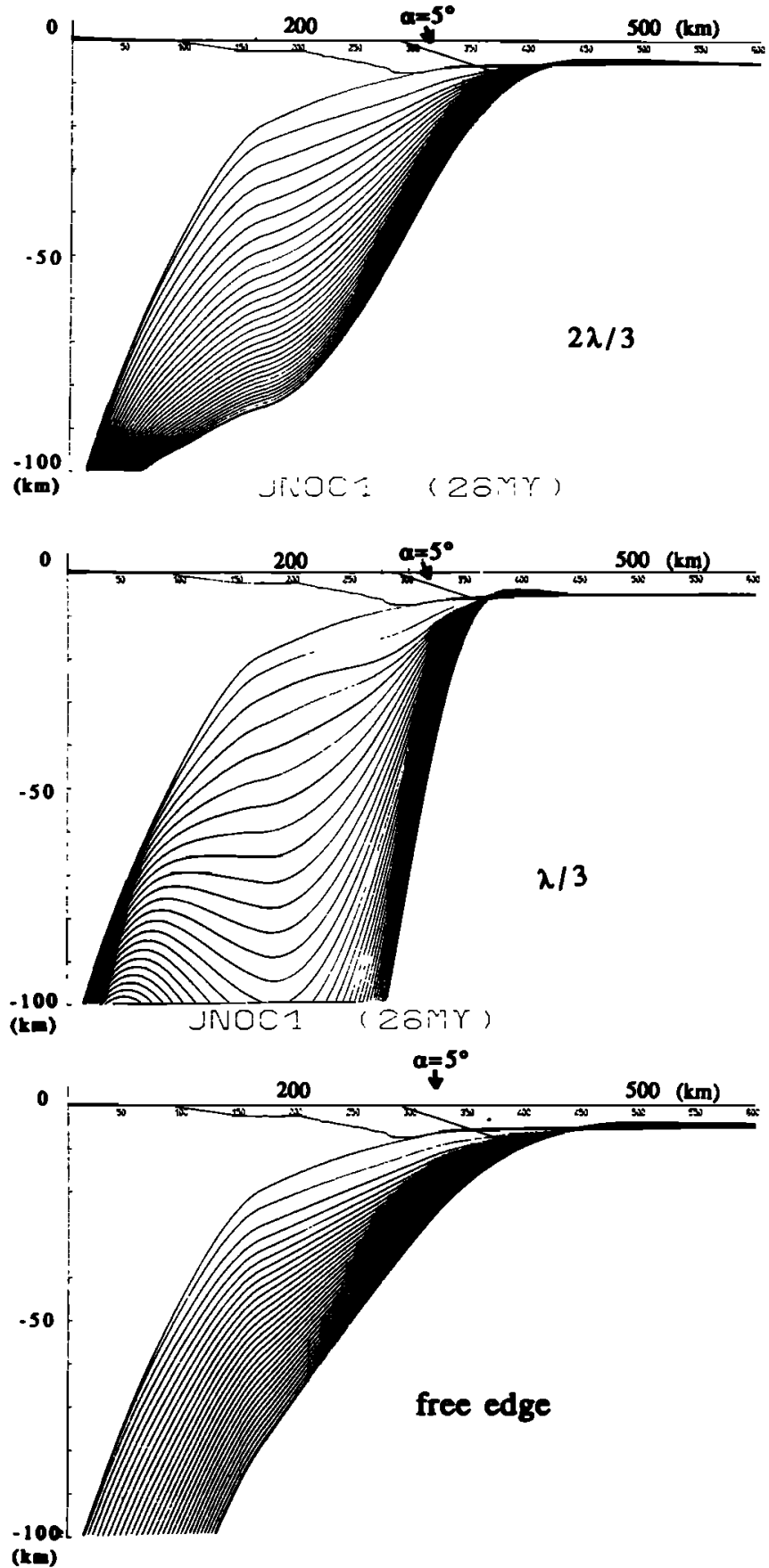

Fig. 8. Different reconstructed geometries of Japan Trench margin along JNOC 1 at $26 \mathrm{Ma}$ showing the effects when changing parameters like the paleoslope dip angle, the flexural parameter, or the boundary conditions. Corrected modem and ancient positions of the $26 \mathrm{Ma}$ seafloor are drawn. The intermediate deflected slabs are drawn every 3 iterations, and the optimal slab geometry converges downward generally after a hundred iterations. See explanations in the text.

$T e=41.0 \mathrm{~km})$ and the past configuration $(60 \mathrm{Ma}$ of backtracked crustal age, von Huene and Lallemand [1990] $\rightarrow \alpha$ $=0.0146 \mathrm{~km}^{-1} ; \lambda=68.6 \mathrm{~km} ; \mathrm{Te}=27.9 \mathrm{~km}$ ). This reconstruction appears the most conservative. Figures $8 b$ and $8 c$ show the consequences on the downward displacement of slab profile when we change the dip of paleoslope from $5^{\circ}$ to, respectively, $3^{\circ}$ and $1^{\circ}$. The deflected area increases significantly (twice larger from $5^{\circ}$ to $1^{\circ}$ ), but these last configurations are probably more realistic because $5^{\circ}$ is presently an overcritical slope angle [Lallemand and Le Pichon, 1987] and because point A does not necessarily represent the paleo-coastline. Figure $8 d$ and $8 e$ keep the $5^{\circ}$ paleoslope angle and show the effect of a change in the flexural parameter. They are, respectively, $2 / 3$ and $1 / 3$ of $\lambda$. Such lower flexural rigidities produce unrealistic slab shapes mainly because of the infinite plate hypothesis which does not allow 
the slab to move deeply, but such parameters are, again, probably more realistic because we intuitively know that the elastic core thins downward due to the reheating of the slab. Furthermore, a decrease of the flexural rigidity provides reconstructions more similar to those produced with an isostatic model which was tested with great success in the first part of this paper but cannot be inverted for instability reasons. The deflected area drastically increases when reducing the flexural rigidity. Figure $8 f$ shows the effect of a semiinfinite plate with a free edge at the origin. In this case, the whole slab migrates landward through time, and considerable amount of material has been removed, especially downward. This also may be not unrealistic because it would explain the earlier presence of the volcanic arc at site 439 of DSDP [as suggested by von Huene et al., 1982].

In terms of removed material, it is very difficult to provide definite estimates because the deflection propagates downward and sometimes increases downward. In order to compare our estimates with the previous minimum estimates proposed by von Huene and Lallemand [1990], we take into account only the arc crust removal. The present Moho discontinuity, under the lithospheric wedge is located at $25-30 \mathrm{~km}$ depth [Yoshii, 1977; Okada et al., 1979]. We do not know the paleodepth of this discontinuity but we assume that the change in depth during Neogene time was not significant. Consequently, we propose estimates of removed material above $20 \mathrm{~km}$ and $30 \mathrm{~km}$ depths. Such depths are reasonnable for estimates of the erosion of the arc's crustal mass (Table 2). One can notice that the decrease of flexural parameter or free boundary condition has little effect on the deflected area above $20 \mathrm{~km}$. The major effects of such conditions are expressed deeper.

In the following reconstructions, we use the most conservative computation, that is, a paleoslope dip angle of $5^{\circ}$, an infinite plate, and a flexural parameter deduced directly from the age of subducting crust. This provides new minimum estimates (the previous minimum estimates being those given by von Huene and Lallemand [1990]), but we have seen that the more realistic reconstructions produced larger estimates.

Figure 9 represents the two northern transects at $26 \mathrm{Ma}, 23$ $\mathrm{Ma}, 16 \mathrm{Ma}$, and present. We observe significant lateral variations along two transects only $100 \mathrm{~km}$ apart. The deflected area along JNOC 1 is twice as much as that of JNOC 2. The large deflected effect along JNOC 1, caused by the first (between 26 and $23 \mathrm{Ma}$ ) limited landward subsidence isolating the Oyashio paleoland (see details in a later section), is mainly due to the density distribution over the lithospheric wedge which increases landward. Table 3 summarizes the deflected area estimates at different times along the two transects.

Two reconstructions have been made along the southern transects at $26 \mathrm{Ma}$ in order to obtain a general perspective view of the Japan Trench margin at this time (Figures $10 a$ and 10b). If the unconformity is of the same nature as in the northern part, it shows that tectonic erosion of the margin since upper Oligocene is not a local process but rather implies that it occurred along the whole Japan margin. Moreover, a multichannel line P 856 across the southern Kuril Trench preliminarily processed by S.E. Lallemand et al. (unpublished data, 1986) and reprocessed by P. Schnurle et al. (unpublished data, 1991) exhibits the same type of unconformity at approximately the same depth. The deflected areas along H.D.79 line reach 2150 and $3250 \mathrm{~km}^{3} / \mathrm{km}$ of trench above, respectively, 20 and $30 \mathrm{~km}$, and 2200 and $2950 \mathrm{~km}^{3} / \mathrm{km}$ along P 844 line. The landwardmost possible location of the paleotrench at $26 \mathrm{Ma}$ is shown in Figure $10 \mathrm{a}$. The minimum trench retreat reaches $80 \mathrm{~km}$ both in the northern and southern part. A global estimate of the volume of rock removed over the whole Japan margin ( $800 \mathrm{~km}$ long) since $26 \mathrm{Ma}$ is about 1.7 million $\mathrm{km}^{3}\left(0.06 \mathrm{~km}^{3} / \mathrm{yr}\right.$ or $80 \mathrm{~km}^{3} / \mathrm{m}$.y./km of trench) above the $20 \mathrm{~km}$ depth limit. Considering a convergence rate of 10 $\mathrm{cm} / \mathrm{yr}$, that corresponds to the continuous erosion of a $800-\mathrm{m}$ thick layer of continental crust over 26 m.y.. This considerable amount of removed material can be divided into two components. One is the frontal erosion which can be estimated to be equivalent of a 200 -m-thick layer continuously subducted through the filling of grabens of the subducting plate [see von Huene and Lallemand, 1990], the other is basal erosion which can be estimated to be equivalent of a $600-\mathrm{m}$ thick layer continuously subducted.

These estimates are roughly 2 times higher than those proposed by von Huene and Lallemand [1990], and the real removed volumes are probably higher because of the previous considerations on paleoslope dip angle, flexural parameter and free edge. The main reason for this discrepancy is that von Huene and Lallemand used a constant density $\left(2.7 \mathrm{~g} / \mathrm{cm}^{3}\right)$ when applying isostatic compensation. The deflection was thus concentrated below the area of subsidence, and the authors justified their simple approach by arguing that it was a minimum estimate comparable to known rates of accretion.

\section{The Example of the Peru Trench}

We have tested our model for the CDP 1 transect described by von Huene and Lallemand [1990] using the same initial geometries at 20 and $8 \mathrm{Ma}$. In this region, subsidence estimates come from the results of ODP Leg 112 [von Huene et al., 1989]. We have also tested the effect of changing parameters for the two reconstructions.

Figures 11 and 12 present the results for 20 and $8 \mathrm{Ma}$. The change of the different parameters of reconstruction produces effects similar to those previously described for the Japan margin, that is to say, an increase of the deflected area when

TABLE 2. Estimated Deflected Areas Using Different Parameters

\begin{tabular}{|c|c|c|c|c|}
\hline \multirow[b]{2}{*}{$\alpha u$} & \multicolumn{3}{|c|}{ Infinite Plate } & \multirow{2}{*}{$\frac{\text { Semi-infinite Plate }}{x}$} \\
\hline & $x$ & $2 \times 3$ & $x / 3$ & \\
\hline \multirow[t]{2}{*}{$5^{\circ}$} & 2450 & 2800 & 2550 & 2750 \\
\hline & 3750 & 4700 & 4400 & 4500 \\
\hline \multirow[t]{2}{*}{$3^{\circ}$} & 3000 & & & \\
\hline & 4500 & & & \\
\hline \multirow[t]{2}{*}{$1^{\circ}$} & 4750 & & & \\
\hline & 6900 & & & \\
\hline
\end{tabular}

$\alpha$ is the paleoslope dip angle; $\lambda$ is the flexural parameter. For each pair of numbers the upper number is for above $20 \mathrm{~km}$ and the lower number is for above $30 \mathrm{~km}$. Numbers are given in square kilometers of cross-sectional areas or in cubic kilometers per kilometer of trench. 

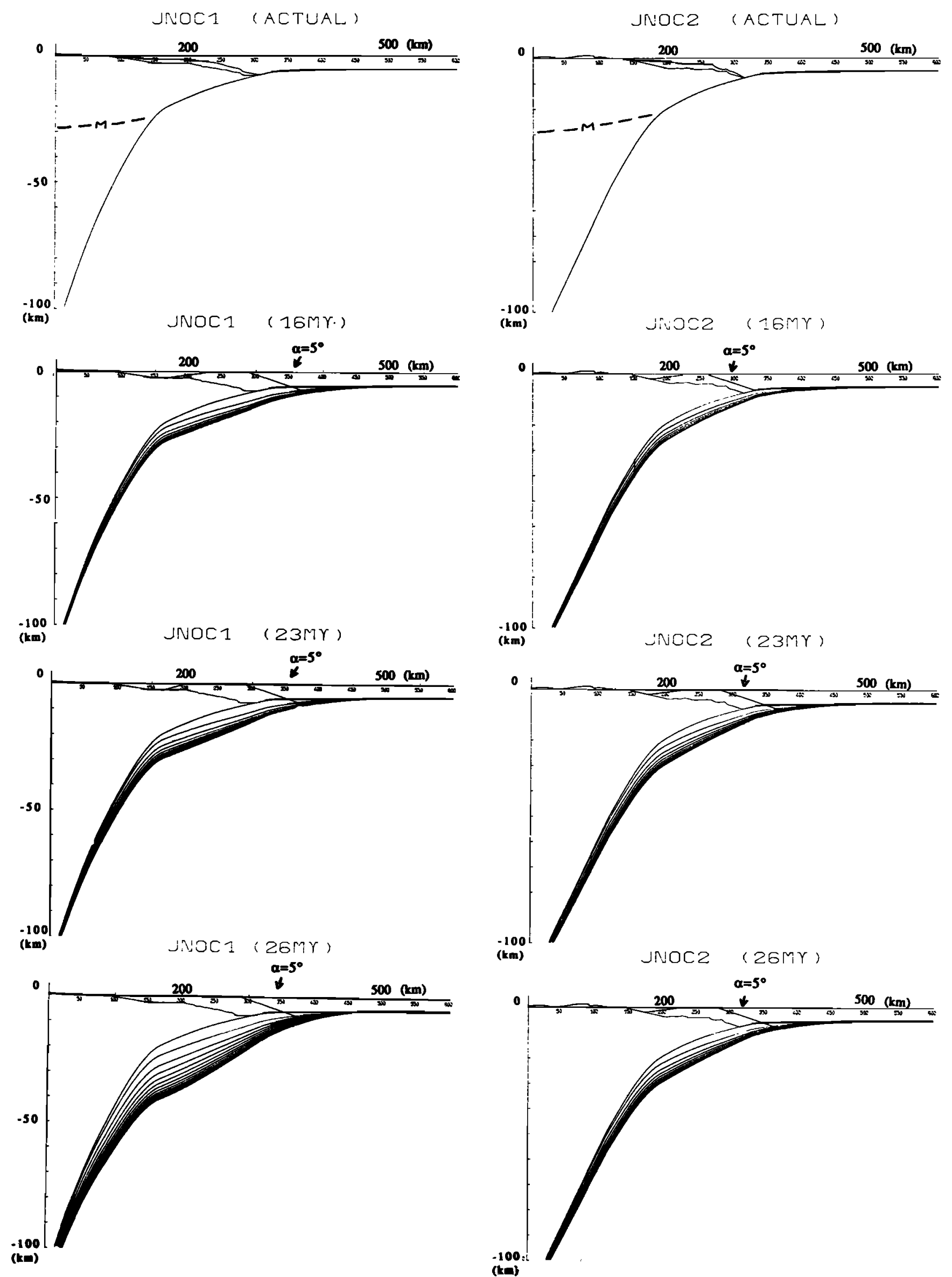

Fig. 9. Reconstructed geometries of Japan Trench margin along two transects JNOC 1 and JNOC 2 - P 849 at different periods: $26 \mathrm{Ma}, 23 \mathrm{Ma}, 16 \mathrm{Ma}$, and present. The approximate location of the Moho discontinuity is figured only for present geometries because we ignore where this discontinuity was located in the past. Corrected modern and ancient positions of the 16,23 , and $26 \mathrm{Ma}$ seafloors are drawn. For the actual configurations (top), the present seafloor and the $26 \mathrm{Ma}$ unconformity are drawn without any corrections. 
TABLE 3. Estimated Deflected Areas Along the Two Northem Transects at Three Different Periods

\begin{tabular}{|c|c|c|c|c|c|}
\hline \multirow[b]{3}{*}{ Periods } & \multicolumn{5}{|c|}{ Downward Limit of Removal } \\
\hline & $20 \mathrm{~km}$ & $30 \mathrm{~km}$ & & $20 \mathrm{~km}$ & $30 \mathrm{~km}$ \\
\hline & \multicolumn{2}{|c|}{ JNOC 1 Line } & ORI 78-4 & \multicolumn{2}{|c|}{ JNOC 2 and $P 849$ Lines } \\
\hline $\begin{array}{l}26 \mathrm{Ma} \\
23 \mathrm{Ma} \\
16 \mathrm{Ma}\end{array}$ & $\begin{array}{l}2450 \\
1900 \\
1700\end{array}$ & $\begin{array}{l}3700 \\
2500 \\
2150\end{array}$ & $800-1100^{*}$ & $\begin{array}{l}1450 \\
1450 \\
1000\end{array}$ & $\begin{array}{l}2000 \\
2000 \\
1300\end{array}$ \\
\hline
\end{tabular}

Values are in square kilometers or cubic kilometers per kilometer of trench.

* This estimate was provided by von Huene and Lallemand [1990] along the ORI 78-4 transect located between JNOC 1 and 2.

paleoslope dip angle decreases from $7.5^{\circ}$ (present lower slope angle) to $3^{\circ}$ because the load increases. A larger deflected area is obtained when the flexural parameter decreases by $2 / 3$ and $1 / 3$. The shape of the slab obtained with $\lambda / 3$ is clearly unrealistic, but it is mainly due to the fixed origin. One can imagine that a free edge allows the slab to migrate landward as in the Japan case; it does not happen here because of the initial configuration of the slab, whose dip angle decreases at depths deeper than $50 \mathrm{~km}$, and we observe a "flag effect" which is an artifact of the iterative method. The estimates of removed material above 20 and $30 \mathrm{~km}$ depths are summarized in Table 4 and compared with the first minimum estimates of von Huene and Lallemand. We generally obtain estimates twice as large as previously published estimates for the same reasons detailed above.

\section{Discussion}

We have seen, when testing the method at present time, that we are able to fit every slab by loading it by the difference in weight with other lithospheric wedges with an error bar less than $2 \mathrm{~km}$ for the isostatic method (no oceanic plate rigidity) and less than $3 \mathrm{~km}$ for the elastic model (oceanic plate rigidity is maximum, function of the mean age) with some exceptions. These exceptions can easily be attributed to the wide transect sampling, including margins as different as Costa Rica and Peru, and also to some regional pertubations due to ridge subductions in Tonga for example. For computing reasons, despite its better fit, the isostatic method cannot be inverted for paleoreconstructions. Nonetheless, the elastic method is more or less similar to the isostatic one when very low flexural parameters are used. A variable flexural parameter is probably the best solution and will be tested as soon as we are able to constrain these downward variations (P. Schnurle et al., manuscript in preparation, 1991). For instance, minimum estimates can be proposed with the elastic method using overestimated rigidities. Furthermore, the error is considerably reduced when comparing the same margin at different periods, especially no older than Neogene time.

The global estimates can be converted into erosion rates and compared with known rates of accretion. These rates can be understood either in square kilometers per million of years of eroded cross-sectional areas along a given transect or in cubic kilometers per million of years per kilometer of margin. They are summarized in Table 5 . This table shows how the changes in rate of erosion through time may be important. The rates in Peru for example are twice as high during the last $8 \mathrm{~m} . y$. compared with the previous $12 \mathrm{~m}$.y.. This large increase in erosion rates coincides exactly with the oblique subduction of the Nazca ridge along this transect (see von Huene and
Lallemand [1990] for further explanations). Concerning Japan, the average rate of erosion is about $100 \mathrm{~km}^{2} / \mathrm{m} . \mathrm{y}$. except for JNOC 2 and P 849 where it is half of this value. These results show that erosion is a global phenomenon at

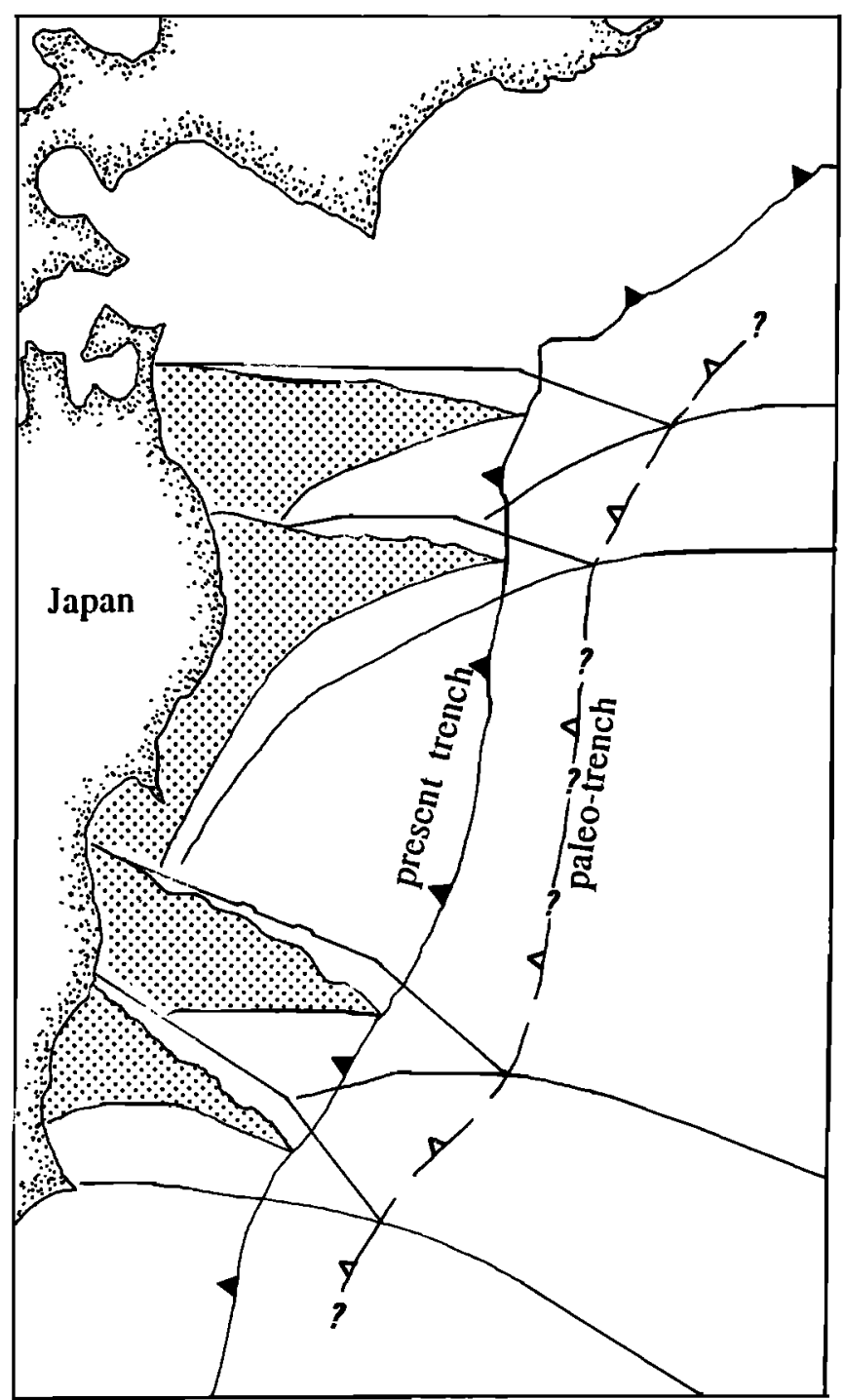

Fig. 10a. Rough perspective reconstructed view of Japan Trench margin, from north to south at $26 \mathrm{Ma}$ with the location of the landwardmost possible paleotrench. Dotted areas represent the present lithospheric wedges outlined by the present bathymetry and Benioff zone. The other contours represent the possible paleobathymetry and slab. 


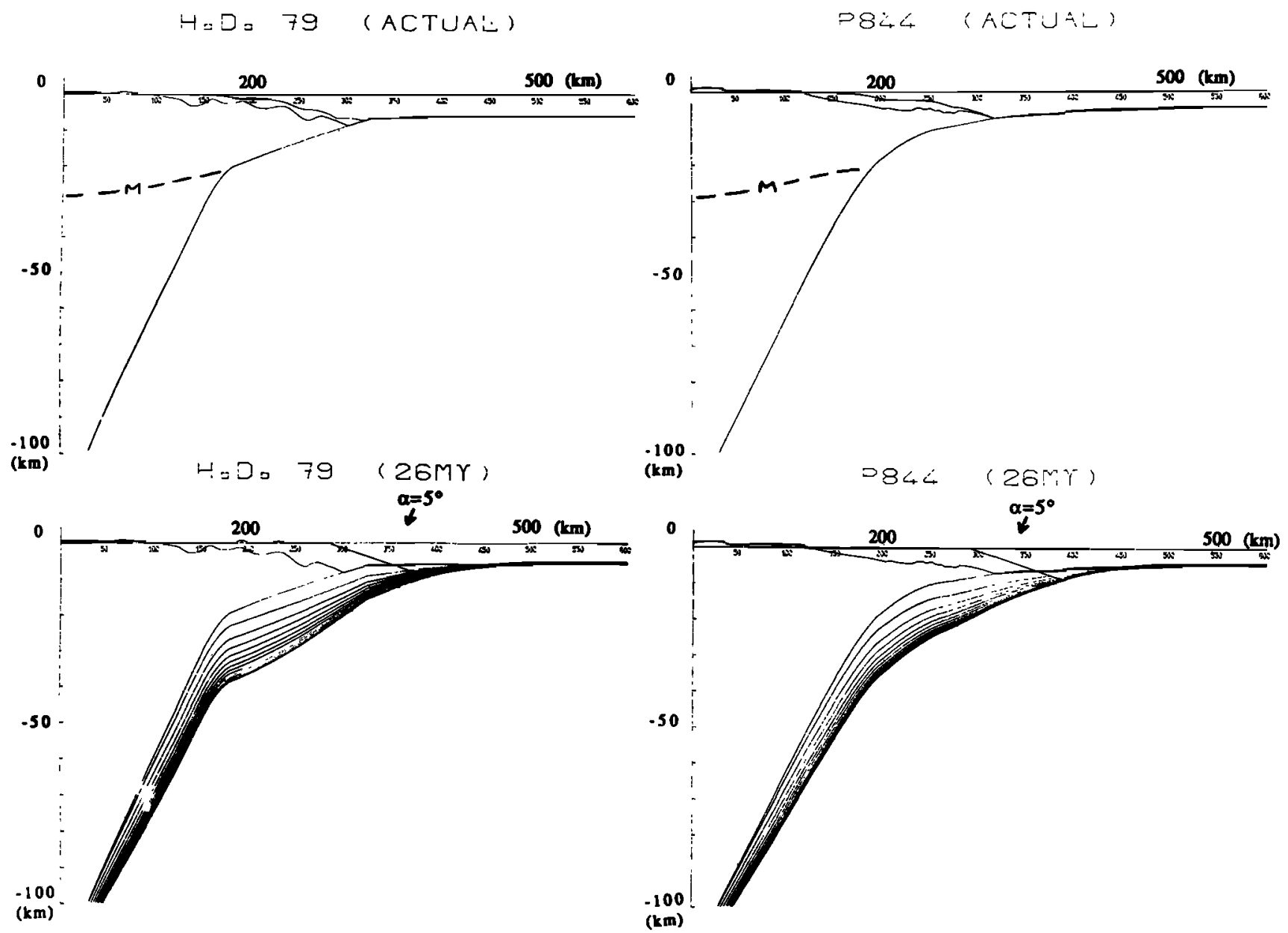

Fig. 10b. Reconstructed geometries of Japan Trench margin along H.D. 79 and P 844 at $26 \mathrm{Ma}$ and present: (top) present bathymetry and unconformity and (bottom) corrected modem and ancient positions of the paleoseafloor area.

least at the scale of the Japan margin. The northernmost transect is rapidly eroded between 26 and $23 \mathrm{Ma}$ while erosion is not recorded $100 \mathrm{~km}$ southward during this time interval. An interpretation will be proposed in the following section.

Tectonic erosion is thus a fundamental aspect when quantifying the loss of crustal material at subduction zones because $100 \mathrm{~km}^{2} / \mathrm{m} . y$. of eroded material with a $10 \mathrm{~cm} / \mathrm{yr}$ subduction rate is equivalent to subducting continuously a 1 $\mathrm{km}$-thick arc crustal layer in addition to the nearly $10-\mathrm{km}$-thick oceanic crust, that is to say, $10 \%$ more. In terms of removal of mass continental crust, about one third of the arc crustal volume (between the present volcanic arc and the Moho discontinuity) was eroded during the last $26 \mathrm{~m} . y$. along the Pacific coast of Japan. We can also consider that this calculation provides a balance between erosion and accretion which can be active simultaneously or, alternatively, as was described by von Huene [1984a, $b, 1985]$.

Concerning the Japan Trench, we observe a general subsidence of the margin that began near the coastline of northem Japan in late Oligocene and was then extended to the whole margin after early Miocene. One interpretation could be the following.

1. During the Paleogene, the present Japan margin was subaerial as attested by a well-documented unconformity, and then submerged across much of the width of the Japan margin.
The 30-Ma volcanic arc was located slightly west of the present one [Ohguchi et al., 1989], and the Eocene volcanic arc is recognized only in Sikhote Alin on the western side of the Japan Sea [Baskina and Volchanskaya, 1972]. The eastward Paleogene jump of the volcanic arc, including the late Eocene to late Oligocene gap in volcanic activity [Tsuchi, 1979; Konda and Uyeda, 1980], may be related to the subduction/collision of a large ridge or microcontinent. Engebretson et al. [1985] noticed drastic changes in rate and motion of the Pacific plate relative to Eurasia during the Eocene. Charvet and Fabbri [1987] invoke the collision of a ridge (the "Kuroshio Paleoland") during the Eocene phase of the Shimanto orogeny in southwest Japan in order to explain the tectonic evolution of this region. This block may constitute part of the basement of the present margin.

2. From late Oligocene to middle Miocene (see Figure 13), a dextral transtensional stress-field prevails on both sides of Northern Honshu Island leading to the opening of the Japan Sea [Lallemand and Jolivet, 1985; Jolivet et al., 1991]. This timing was controversial for a long time but was finally demonstrated by ODP legs 127-128 in 1989 [ [ Leg 127 Scientific Party, 1990; Tamaki et al., 1990]. The subsidence of probably small pull-apart forearc basins was contemporaneous to these events isolating the Oyashio paleoland from the main Honshu Island. Due to the dextral motion along the southern 

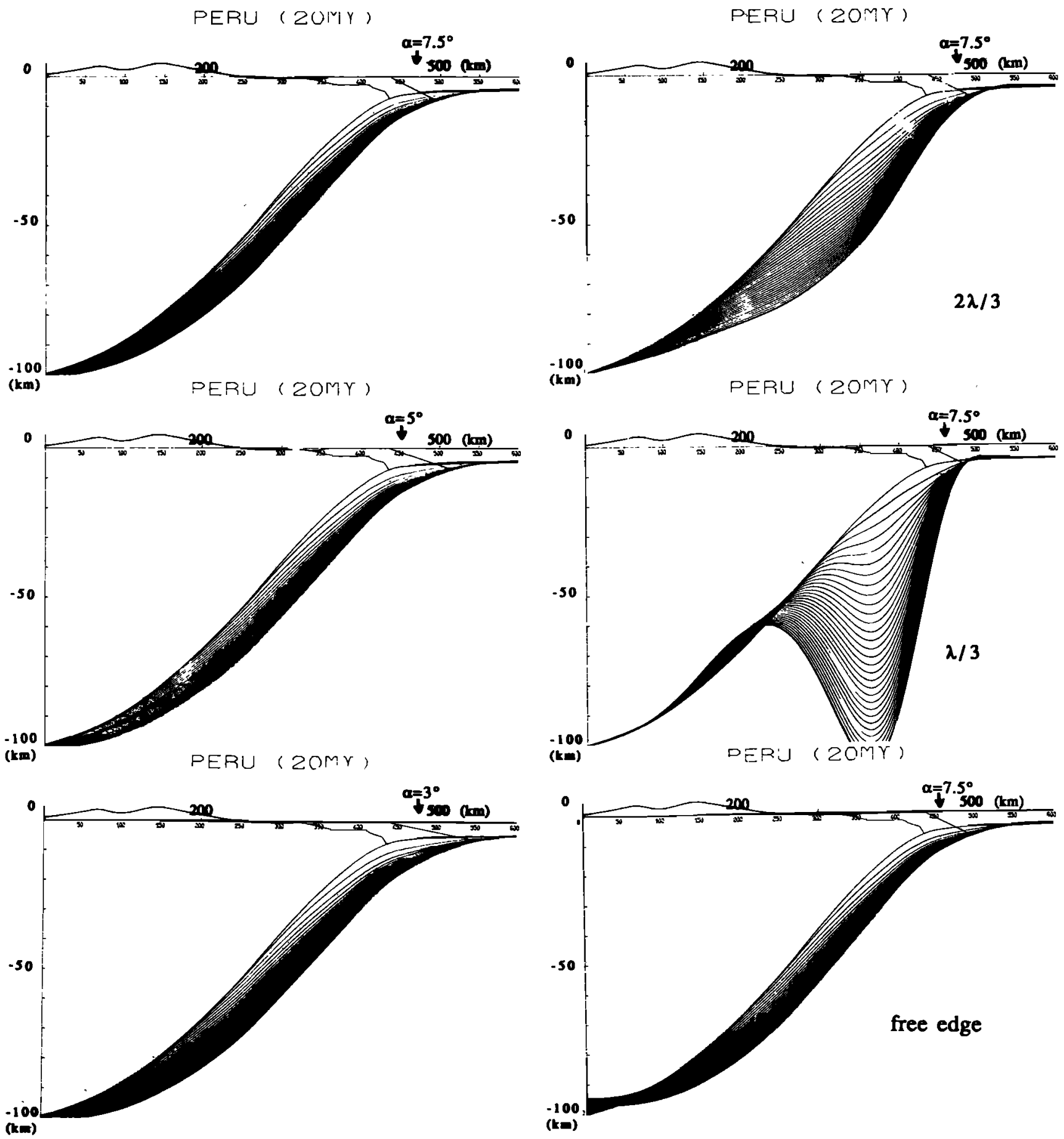

Fig. 11. Different reconstructed geometries of Peru Trench margin along CDP 1 at 20 Ma showing the effects when changing parameters like the paleoslope dip angle, the flexural parameter, or the boundary conditions. Corrected modem and ancient positions of the $20 \mathrm{Ma}$ seafloor are drawn. See explanations in the text.

extension of the Hidaka Shear Zone [Jolivet and Miyashita, 1985; Jolivet and Huchon, 1989], a temporary growth of the Japanese margin may also have occurred off northern Japan and perturbated the previous equilibrium of the margin by loading its front. The 29-m.y. old homfels dredged along the main scarp (on the seismic line ORI 78-4) of the northern Japan Trench margin (see Figure 2) may come from the basement of the ocean side block. The same biotite-bearing hornfels exists on the eastern flank of the Hidaka mountains. They are linked with the 17-41 Ma plutonic intrusions [Kimura et al., 1983; Komatsu et al., 1983]. Thus it is more reasonable to explain the occurrence of these homfels by a N-S translation along a well-constrained shear zone rather than to relate them to the thermal metamorphism associated with the 21-Ma igneous event observed at site 439 and located $100 \mathrm{~km}$ away (this last explanation was proposed by Takigami and Fujioka [1989]). According to the geodynamic context, it is tempting to relate the obscured area seen below the midslope terrace of seismic 

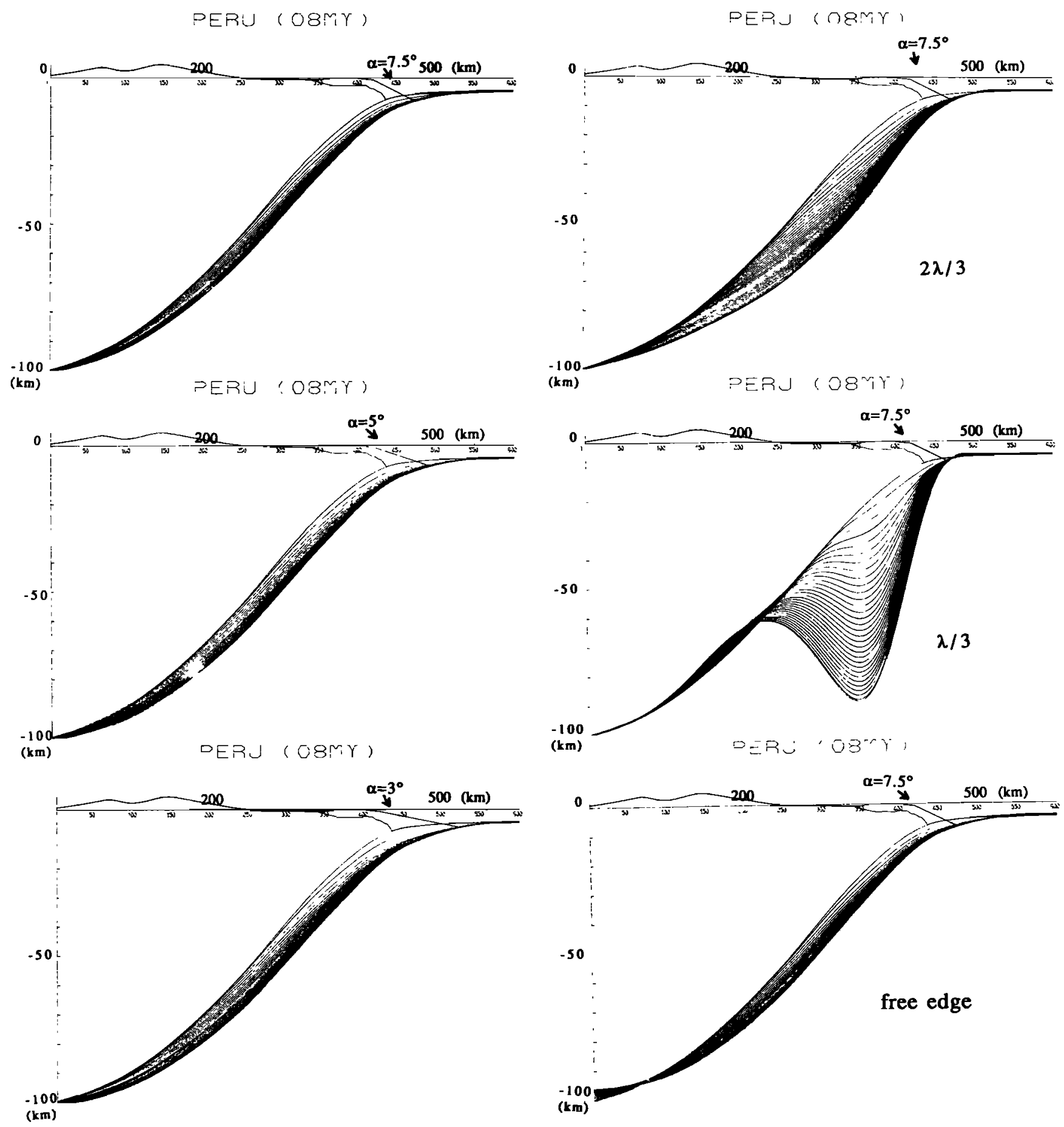

Fig. 12. Different reconstructed geometries of Pen Trench margin along CDP 1 at $8 \mathrm{Ma}$ showing the effects when changing parameters like the paleoslope dip angle, the flexural parameter or the boundary conditions.Corrected modem and ancient positions of the 8 Ma seafloor are drawn. See explanations in the text.

line ORI 78-4 (see von Huene and Culotta [1989], and Figure 1) to the southward end of the Hidaka Shear Zone, the ocean side block being allochtonous from the north. In this hypothesis, a triple junction (trench-trench-transform) was active somewhere in the Japan Trench at least in late Oligocene to early Miocene. Both forearc extension and seaward rapid growth of the margin may be responsible for the early Miocene volcanism registered at site 439 and the rapid subcrustal tectonic erosion quantified in our model, especially in the northernmost part.
3. From middle Miocene to present, the Japan Trench margin has been subsiding as a whole with a differential increase in amplitude seaward as attested by the present seaward dip of the unconformity. This differential movement has been recently simulated using sandbox modeling (S.E. Lallemand et al., manuscript in preparation, 1991). As a matter of fact, the subcrustal erosion effect on a non-accretionary margin is mainly a subsidence of the frontal part of the prism which nourishes the subcrustal erosion process. One can easily 
TABLE 4. Comparison of Estimates of Removed Material Along CDP 1 Transect (Peru) Above 20 and $30 \mathrm{~km}$ Depth at 20 and $8 \mathrm{Ma}$

\begin{tabular}{|c|c|c|c|c|c|c|c|}
\hline \multirow[b]{2}{*}{$\alpha$} & \multirow[b]{2}{*}{$\lambda$} & \multicolumn{3}{|c|}{$20 \mathrm{Ma}$} & \multicolumn{3}{|c|}{$8 \mathrm{Ma}$} \\
\hline & & $20 \mathrm{~km}$ & VHL* & $30 \mathrm{~km}$ & $20 \mathrm{~km}$ & VHL* & $30 \mathrm{~km}$ \\
\hline \multicolumn{8}{|c|}{ Infinite Plate } \\
\hline $\begin{array}{r}7.5^{\circ} \\
5^{\circ} \\
3^{\circ} \\
7.5^{\circ} \\
7.5^{\circ}\end{array}$ & $\begin{array}{r}x \\
x \\
x \\
2 x / 3 \\
x / 3\end{array}$ & $\begin{array}{l}1200 \\
1400 \\
1800 \\
1400 \\
1400\end{array}$ & $500-600$ & $\begin{array}{l}1700 \\
2000 \\
2500 \\
2200 \\
2500\end{array}$ & $\begin{array}{c}700 \\
900 \\
1200 \\
900 \\
1000\end{array}$ & $300-400$ & $\begin{array}{l}1100 \\
1300 \\
1700 \\
1500 \\
1850\end{array}$ \\
\hline \multicolumn{8}{|c|}{ Semi-infinite Plate } \\
\hline $7.5^{\circ}$ & $x$ & 1200 & & 1800 & 750 & & 1100 \\
\hline
\end{tabular}

Estimates are given in square kilometers or in cubic kilometers per kilometer of trench for two deep boundaries, 20 and $30 \mathrm{~km} ; \alpha$ and $\lambda$ are respectively the paleoslope dip angle and the flexural parameter.

* Cross-sectional area calculated by von Huene and Lallemand (VHL) [1990]; see further explanations in the text.

TABLE 5. Minimum Rates of Erosion Along the Studied Transects

\begin{tabular}{|c|c|c|}
\hline & Above $20 \mathrm{~km}$ & Above $30 \mathrm{~km}$ \\
\hline \multicolumn{3}{|c|}{ Japan } \\
\hline Whole Japan Margin since $26 \mathrm{Ma}$ & 80 & 115 \\
\hline \multicolumn{3}{|l|}{ JNOC 1 transect } \\
\hline since $26 \mathrm{Ma}$ & 95 & 145 \\
\hline between 26 and $23 \mathrm{Ma}$ & 185 & 400 \\
\hline between 23 and $16 \mathrm{Ma}$ & 25 & 50 \\
\hline since $16 \mathrm{Ma}$ & 110 & 135 \\
\hline \multicolumn{3}{|l|}{ JNOC 2 - P 849 transect } \\
\hline since $26 \mathrm{Ma}$ & 55 & 75 \\
\hline between 26 and $23 \mathrm{Ma}$ & 0 & 0 \\
\hline between 23 and $16 \mathrm{Ma}$ & 50 & 70 \\
\hline since $16 \mathrm{Ma}$ & 60 & 80 \\
\hline H.D. 79 transect since $26 \mathrm{Ma}$ & 85 & 125 \\
\hline \multirow[t]{2}{*}{ P 844 transect since $26 \mathrm{Ma}$} & 85 & 115 \\
\hline & Peru & \\
\hline \multicolumn{3}{|l|}{ CDP 1 transect } \\
\hline since $20 \mathrm{Ma}$ & 60 & 85 \\
\hline between 20 and $8 \mathrm{Ma}$ & 35 & 55 \\
\hline since $8 \mathrm{Ma}$ & 95 & 135 \\
\hline
\end{tabular}

Rates are given in cubic kilometers per million of years per kilometer of trench.

imagine that the successive presumed incorporation of allochtonous blocks (a northern extension of the Kuroshio Paleoland and a southem extension of the Hidaka block) plus the forearc extension due to transtension perturbated the equilibrium of the margin drastically and the erosional process acted as a "cure". Then, the slab probably migrated landward simultaneously with the volcanic arc which reached its present position at $12 \mathrm{Ma}$ [Tsunakawa, 1986].

\section{ConClusion}

It appears from this study that tectonic erosion is a response to a perturbative effect which can be either the subduction of a ridge, the accretion of a large continental block, a change in kinematics, or forearc extension. Lallemand and Le Pichon [1987], von Huene and Lallemand [1990], and Lallemand et al. [1990] discussed in detail the effects of seamount subduction on tectonic erosion. Similar processes could be found for explaining the accretionary process such as the sediment supply in the trench and so on. There is no definite answer to the question: Is it the geometry of the slab or of the lithospheric wedge that governs the geometry of the other? We think that both interact and always tend to a short-lived equilibrium, but intuitively one can imagine that changes in parameters of large oceanic plates, like the Pacific plate, is responsible for the tectogenesis of plate rims. Furthermore, periods of tectonic erosion affecting the active margins are associated with periods of uplift of the associated arc, suggesting that the removal of crustal material perturbs the equilibrium of the whole lithospheric wedge including the volcanic arc. As soon as new data on vertical movements at convergent margins become available, we will extend our study to other active margins to complete the tectonic erosion contribution to the loss of material in subduction zones. Our simple method will be improved in the near future by testing other models like finite element modeling or by adding elastoplastic behavior. 


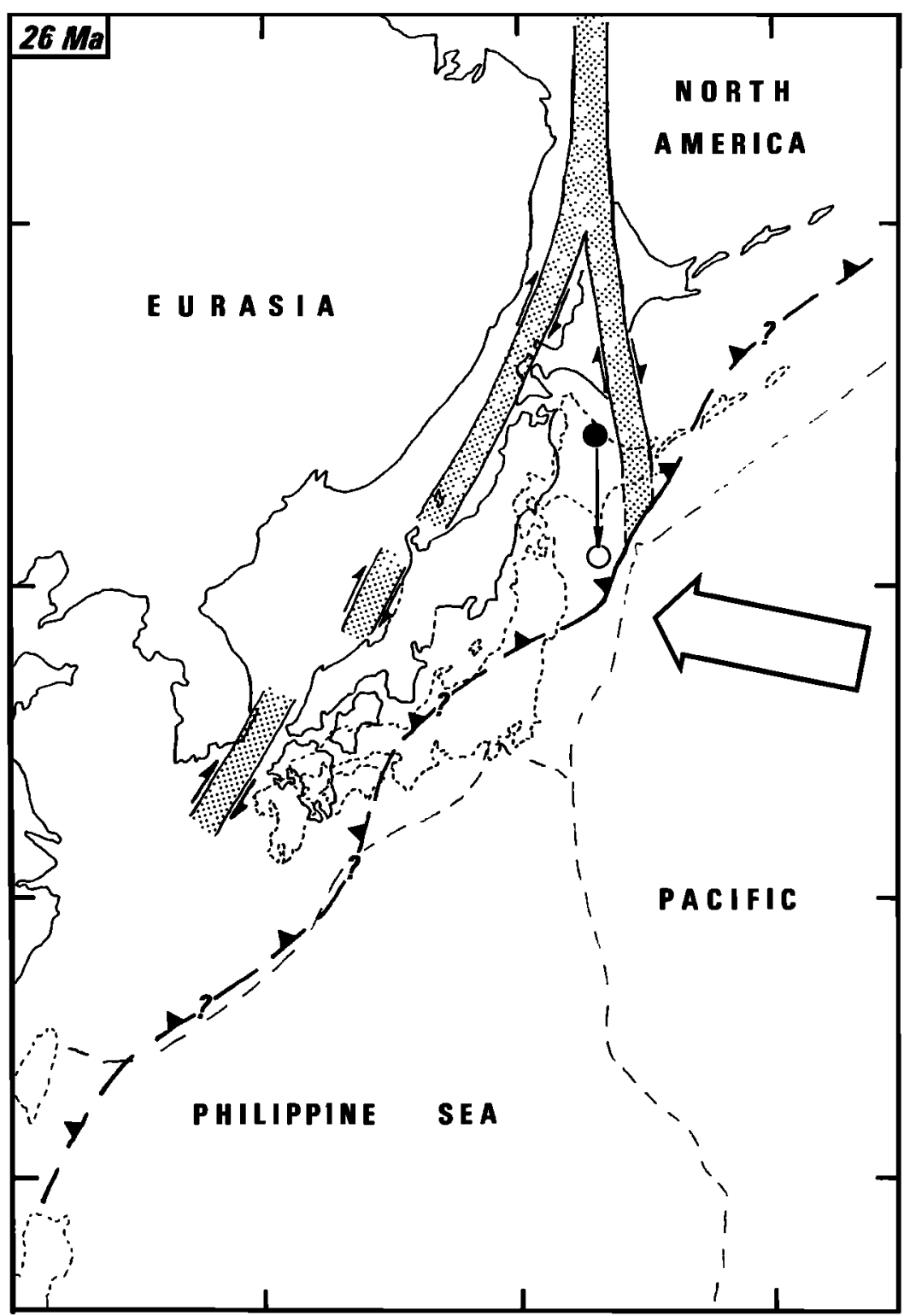

Fig. 13. Reconstruction of Japanese Islands at $26 \mathrm{Ma}$ before the opening of the Japan Sea. The paleo-position of Japan is after Jolivet et al. [1991]. Active right-lateral shear zones are represented by dotted areas. The possible paleotrench location is drawn in heavy lines with triangles and constrained by the previous computations off northeast Japan. DSDP site 439 is represented by a solid circle at $26 \mathrm{Ma}$ and a open circle at Present. Notice the triple junction off northeast Japan. Present plate configuration corresponds to dotted lines. The arrow shows the direction of convergence between Eurasia-North America and Pacific plates during Neogene.

\section{APPENDIX}

\section{Isostasy Equations}

If the system $j$ is considered as the reference state, the isostatically deduced geometry of $i$ is given by :

$$
\begin{aligned}
& H_{\omega_{i}}(x) \cdot \rho_{\omega}+H_{i}(x) \cdot \bar{\rho}_{i}(x)=H_{\omega_{j}}(x) \cdot \rho_{\omega}+H_{j}(x) \cdot \bar{\rho}_{j}(x) \\
& +y(x) \cdot \rho_{m} \\
& H_{\omega_{i}}(x)+H_{i}(x)=H_{\omega_{j}}(x)+H_{j}(x)+y(x) \\
& \bar{\rho}_{i}(x)=\mathbf{f}\left\{H_{i}(x)\right\}
\end{aligned}
$$

where $H_{i}(x)$ is the lithospheric wedge $i$ thickness at horizontal distance $x, H_{\omega_{i}}(x)$ is the water layer $i$ thickness, $\rho_{i}(x)$ is the mean density function of $H_{i}(x)$ (see Figure 3 ), $y(x)$ is the deflection, and $\rho_{m}$ and $\rho_{\omega}$ are the mantle and water densities, respectively, $3.33 \mathrm{~g} / \mathrm{cm}^{3}$ and $1.03 \mathrm{~g} / \mathrm{cm}^{3}$.

(1) $-\rho \omega(2) \Rightarrow$

$$
\begin{aligned}
y(x)=\frac{H_{i}(x) \cdot\left[\bar{\rho}_{i}(x)-\rho_{\omega}\right]-H_{j}(x) \cdot\left[\bar{\rho}_{j}(x)-\rho_{\omega}\right]}{\rho_{m}-\rho_{\omega}} \\
\Rightarrow y(x)=\frac{P_{i}(x)-P_{j}(x)}{k} \\
\Rightarrow y(x)=\frac{P_{i j}(x)}{k} \\
P_{i}(x)=\left[\bar{\rho}_{i}(x)-\rho_{\omega}\right] g H_{i}(x)
\end{aligned}
$$




$$
k=\left(\rho_{m}-\rho_{\omega}\right) g
$$

where $g$ is the acceleration of gravity. $P_{i}(x)$ represents the weight of the lithospheric wedge where the density has to be corrected for Archimede's principle and $k$ is the hydrostatic restoring force. Thus $S_{i j}{ }_{i j}(x)=S_{j}(x)+y(x)$ is the isostatically computed depth of slab $S_{i}$ deflected from state $S_{j}$ by loading with $P_{i j}$.

\section{Elasticity Equations for an Infinite Beam}

$$
\begin{aligned}
y_{\infty}(x) & =\int_{-\infty}^{+\infty} d x^{\prime} \frac{P_{i j}\left(x^{\prime}\right)}{k} A_{\alpha x}\left(x-x^{\prime}\right) \\
\text { with } A_{\alpha x} & =\frac{\lambda}{2} \mathrm{e}^{-\lambda x}[\cos (-\lambda x)+\sin (-\lambda x)]
\end{aligned}
$$

Thus:

$$
y_{\infty}(x)=\int_{-\infty}^{+\infty} d x^{\prime} \frac{P_{i j}\left(x^{\prime}\right)}{k} \frac{\lambda}{2} \mathrm{e}^{-\lambda\left|x-x^{\prime}\right|}\left[\cos \left(-\lambda\left|x-x^{\prime}\right|\right)+\sin \left(-\lambda\left|x-x^{\prime}\right|\right)\right]
$$

The resulting slab deduced from state $S_{j}$ is $S^{e} i j(x)=S_{j}(x)+y_{\infty}(x)$.

\section{Elasticity Equations for a Semi-infinite Beam}

The end conditioning boundary forces at origin are applied to the previous equations as follows:

$$
\text { applied on } A_{\alpha_{x}} \quad P_{0}=4\left(\lambda M_{\infty}(0)+Q_{\infty}(0)\right)
$$

and

$$
\text { applied on } B_{\alpha x} \quad M_{0}=-2\left(\left(Q_{\infty}(0) / \lambda+2 M_{\infty}(0)\right)\right.
$$

with

$$
B_{\alpha x}=\frac{\lambda}{2} \mathrm{e}^{-\lambda x} \sin (-\lambda x)
$$

where $P$ is the loading force, $M$ the bending moment, and $Q$ the vertical shearing force [Hétenyi, 1946].

Thus

$$
y(x)=y_{\infty}(x)+\frac{P}{k} * A_{\alpha x}+\frac{M_{o}}{k} * B \alpha_{x}
$$

The resulting slab deduced from state $S_{j}$ is $S_{i j}(x)=S_{j}(x)+y(x)$ using a free edge boundary condition.

\section{Mean Absolute Errors Equations}

$$
\begin{aligned}
& s_{\mathrm{i}}^{i}(x)=\frac{1}{14} \sum S_{i \mathrm{j}}^{i}(x), \\
& S_{\mathrm{i}}^{e}(x)=\frac{1}{14} \sum S_{i j}^{e}(x),
\end{aligned}
$$

and

$$
\begin{gathered}
S_{\mathrm{i}}^{f}(x)=\frac{1}{14} \sum S_{i j}^{f}(x) \\
\sigma_{\mathrm{i}}^{i}\left(z=S_{i}(x)\right)=\frac{1}{14} \sum_{j}\left|S_{i j}^{i}(x)-S_{i}(x)\right|, \\
\sigma_{\mathrm{i}}^{e}\left(z=S_{i}(x)\right)=\frac{1}{14} \sum_{j}\left|S_{i j}^{e}(x)-S_{i}(x)\right|,
\end{gathered}
$$

and

$$
\sigma_{i}^{f}\left(z=S_{i}(x)\right)=\frac{1}{14} \sum_{j}\left|S_{i j}^{f}(x)-S_{i}(x)\right|
$$

The comer diagrams in Figure 6 show the mean absolute error versus depth : $\sigma^{i}(z), \sigma^{e}(z)$, and $\sigma^{f}(z)$ of the various tests which are representative of the error bars of the modelings:

$$
\begin{aligned}
& \sigma^{i}(z)=\frac{1}{15} \Sigma_{i} \sigma_{i}^{i}(z), \\
& \sigma^{e}(z)=\frac{1}{15} \Sigma_{i} \sigma_{\mathrm{i}}^{e}(z),
\end{aligned}
$$

and

$$
f_{(z)}=\frac{1}{15} \Sigma_{i} f_{i}(z)
$$

Acknowledgments. We greatly acknowledge X. Le Pichon, N. Chamot-Rooke, S. J. Lallemant, L. Jolivet, and C. Deplus for their constructive discussions and suggestions; $R$. von Huene is warmly acknowledged for providing precious data on Japan Trench area and for English improvement; D. Scholl, N. Sleep, and D. Byrne for their scientific review and for English improvement of the paper; and F. Farcy for his technical assistance.

\section{REFERENCES}

Addicott, W.O., and P.W. Richards, Plate-Tectonic Map of the CircumPacific Region, Southwest Quadrant, scale 1:10 000 000, CircumPac. Counc. for Energy and Miner. Resour., Am. Assoc. of Pet. Geol., Houston, Tex., 1981a.

Addicott, W.O., and P.W. Richards, Plate-Tectonic Map of the CircumPacific Region, Northwest Quadrant; scale 1:10 000 000, CircumPac. Counc. for Energy and Miner. Resour., Am. Assoc. of Pet. Geol., Houston, Tex., $1981 b$.

Barazangi, M., and B.L. Isacks, Spatial distribution of earthquakes and subduction of the Nazca plate beneath South America, Geology, 4 , 686-692, 1976

Baskina, V.A., and I.K. Volchanskaya, Age of igneous rocks in eastem Sikhote Alin (by K.A method), (in Russian), Dokl., Akad. Nauk SSSR, 204, 667-670, 1972.

Bodine, J.H., et al., Observations of flexure and rheology of the oceanic lithosphere, J. Geophys. Res., 86, 3695-3707, 1981.

Bouysse, P., and D. Westercamp, Effets de la subduction de rides océaniques sur l'évolution d'un arc insulaire: l'exemple des Petites Antilles, Geol. Fr., 2-3, 3.38, 1988.

Briais, A., Cinématique d'ouverture de la Mer de Chine du Sud (NanHai) Implications pour la tectonique tertiaire de l'Asie, Thesis, 240 pp., Paris VI Univ., 1989.

Burbach, G.V., C. Frohlich, W.D. Pennington, and T. Matsumoto, Seismicity and tectonics of the subducted Cocos plate, J. Geophys. Res., 89, 7719-7735, 1984.

Cadet, J.P., K. Kobayashi, J. Aubouin, J. Boulègue, C. Deplus, J. Dubois, R. von Huene, L. Jolivet, T. Kanazawa, J. Kasahara, K. Koizumi, S. Lallemand, Y. Nakamura, G. Pautot, K. Suyehiro, S. Tani, H. Tokuyama, and T. Yamazaki, The Japan Trench and its juncture with the Kuril Trench: Cruise results of the KAIKO project, Leg 3, Earth Planet. Sci. Lett., 83, 267-284, $1987 a$.

Cadet, J.P., K. Kobayashi, S. Lallemand, L. Jolivet, J. Aubouin, J. Boulègue, J. Dubois, H. Hotta, T. Ishii, K. Konishi, N. Niitsuma, and H. Shimamura, Deep scientific dives in the Japan and Kuril Trenches, Earth Planet. Sci. Lett., 83, 313-328, $1987 b$.

Cande, S., Nazca-South America plate interactions since 50 My B.P. to present, in Peru-Chile Trench off Peru, Ocean Drill. Program, Reg. Aulas S., edited by Hussong D.M., Dang St. P., Kulm L.D., Couch R. and Hilde T.W.C., Mar. Sci. Int., Woods Hole, Mass., 1985.

Cardwell, R.K., B.L. Isacks, and D.E. Karig, The spatial distribution of earthquakes, focal mechanism solutions, and subducted lithosphere in the Philippine and northeastern Indonesian islands, in The Tectonic and Geologic Evolution of Southeast Asian Seas and Islands, Geophys. Monogr. Ser., vol. 23, edited by D. Hayes, pp. 135, AGU, Washington, D. C., 1980. 
Cardwell, R., E. Kappel, M. Lawrence, and B. Isacks, Plate convergence along the Indonesian arc (abstract), Eos Trans. AGU, $62,404,1981$.

Carr, M.J., W.I. Rose, and D.G. Mayfield, Potassium content of lavas and depth to the seismic zone in Central America, $J$. Volc. and Geotherm. Res., 5, 387-401, 1979.

Chamot-Rooke, N., V. Renard, and X. Le Pichon, Magnetic anomalies in the Shikoku Basin: a new interpretation, Earth Planet. Sci. Lett., 83, 214-228, 1987.

Charvet, J., and $O$. Fabbri, Vue générale sur l'orogénèse Shimanto et l'évolution tertiaire du Japon sud-ouest (in French with English abstract), Bull. Soc. Geol. Fr., 6, 1171-1188, 1987.

Chase, C.G., Plate kinematics: The Americas, east Africa, and the rest of the world, Earth Planet. Sci. Lett., 37, 355-368, 1978.

Collot, J.-Y., and M.A. Fisher, Crustal structure, from gravity data, of a collision zone in the central New Hebrides island arc, in Geology and Offshore Resources of Pacific Island Arcs - Vanuatu Region, Earth Sci. Ser., vol. 8, edited by H.G. Greene and F.L. Wong, pp. 125-139, Circum-Pacific Council for Energy and Mineral Resources, Houston, Tex., 1988.

Cross, T.A., and R.H. Pilger, Controls of subduction geometry, location of magmatic arcs, and lectonics of arc and back-arc regions, Geol. Soc. Am. Bull., 93, 545-562, 1982.

Davey, F.J., K. Lewis, J.R. Childs, and M.A. Hampton, Convergent margin off east coast of North Island, New Zealand, Parts I and II, in Seismic Images of Modem Convergent Margins Tectonic Structure, edited by R. von Huene, AAPG Stud. Geol. 26, 49-53, 1986.

De Bremaecker, J.C., Is the oceanic lithosphere elastic or viscous?, $J$. Geophys. Res., 82, 2001-2004, 1977.

Dupont, J., Morphologies et structures superficielles de l'arc insulaire des Tonga-Kemadec, in Contribution à l'étude géodynamique du sudouest Pacifique, Trav. Doc. ORSTOM, 147, 263-282, 1982.

Dupont, J., The Tonga and Kermadec Ridges, in The Ocean Basins and Margins, vol. 7B, edited by A.E.M. Naim, F.G. Stehli, and S. Uyeda, pp. 375-409, Plenum , New York, 1988.

Engebretson, D.C., A. Cox and R.G. Gordon, Relative motions between oceanic and continental plates in the Pacific Basin, Spec. Pap. Geol. Soc. Am., 206, 59 Pp., 1985.

Fitch, T.J., and C.H. Scholtz, Mechanism of underthrusting in southwest Japan: A model of convergent plate interactions, $J$. Geophys. Res., 76, 7260-7279, 1971.

Forsyth, D. W., Comparison of mechanical models of the oceanic lithosphere, J. Geophys. Res., 85, 6364-6368, 1980.

Furlong, K.P., Thermal modeling of the geometry of subduction with implications for the tectonics of the overriding plate, J. Geophys. Res., 87, 1786-1802, 1982.

Gnibidenko, H., T.G. Bykova, O.V. Veselov, V.M. Vorobiev, and A.S Svarichevsky. The tectonics of the Kuril-Kamtchatka deep-sea trench, in Geodynamics of the Western Pacific-Indonesian Region, Geodyn. Ser., vol. 11, edited by T.W.C. Hilde and S. Uyeda, pp. 249-285, AGU, Washington, D. C., 1983.

Hagger, B.H., and J.R. O'Connell, Subduction zone dip angles and flow driven by plate motion, Tectonophysics, 50, 11-113, 1978.

Hamburger, M., R.K. Cardwell, and B.I. Isacks, Seismotectonics of the northern Philippine Island arc, in The Tectonic and Geologic Evolution of Southeast Asian Seas and Islands, Part 2, Geophys. Monogr. Ser., vol. 27, edited by D. Hayes, AGU, 1-22, 1983.

Hamilton, W., Tectonics of the Indonesian region, U. S. Geol. Surv. Prof. Pap., 1078, 308 pp., 1979.

Haq, B.U., J. Hardenbol, and P.R. Vail, Chronology of fluctuating sea levels since the Triassic, Science, 235, 1156-1167, 1987.

Hasegawa, A., N. Umino, A. Takagi, S. Suzuki, Y. Motoya, S. Kameya, K. Tanaka, and Y. Sawada, Spatial distribution of earthquakes beneath Hokkaido and northem Honshu, Japan (in Japanese with English abstract), Zisin, 36, 129-150, 1983.

Hashida, T., Three-dimensional seismic attenuation structure beneath the japanese islands and its tectonic and thermal implications, Tectonophysics, 159, 163-180, 1989.

Hayes, D.E., and S.D. Lewis, A geophysical study of the Manila trench, Luzon, Philippines, 1, Crustal structure, gravity, and regional tectonic evolution, J. Geophys. Res., 89, 9171-9195, 1984.

Hetényi, M., Beams on Elastic Foundation, Theory With Applications in the Fields of Civil and Mechanical Engineering. 245 pp., The University of Michigan Press, Ann Arbor ed., 1946.

Hirahara, K., Three-dimensional seismic structure beneath southwest Japan: the subducting Philippine Sea plate, Tectonophysics, 79, 144, 1981.
Ichikawa, M., Reanalyses of mechanism of earthquakes which occurred in and near Japan, and statistical studies on the nodal plane solutions obtained, 1926-1968, Geophys. Mag., 35, 207-274, 1971.

Isacks, B.L., and M. Barazangi, Geometry of Benioff zones: lateral segmentation and downwards bending of the subducted lithosphere Maurice Ewing ser. vol. 1, edited by Talwani, pp. 99-114, AGU, Washington, D. C., 1977.

Iwasaki, T., H. Shimamura, J. Melles, J. Makris, N. Hirata, T. Kanazawa, T. Urabe, and K. Suyehiro, Crust and upper mantle structure in the Ryukyu island arc deduced from DSS, paper presented at 19ih Gen. Assem. IUGG., 1, 326, 1987.

Iwasaki, T., H. Shiobara, A. Nishizawa, T. Kanazawa, K. Suyehiro, N. Hirata, T. Urabe, and $\mathrm{H}$. Shimamura, A detailed subduction structure in the Kuril trench deduced from ocean bottom seismographic refraction studies, Tectonophysics, 165, 315-336, 1989.

James, D.E., Andean crustal and upper mantle structure, J. Geophys. Res., 76, 3246-3271, 1971.

Jolivet, L., and P. Huchon, Crustal scale strike-slip deformation in Hokkaido, northeast Japan, J. Struct. Geol., 11, 509-522, 1989.

Jolivet, L., and S. Miyashita, The Hidaka Shear Zone (Hokkaido Japan): Genesis during a right-lateral strike-slip movement, Tectonics, 4, 289-302, 1985.

Jolivet, L., P. Huchon, J.-P. Brun, X. Le Pichon, N. Chamot-Rooke, and J.-C. Thomas, Arc deformation and marginal basin opening: Japan Sea as a case study, J. Geophys. Res., 96, 4367-4384, 1991.

Jones, P.R., Crustal structure of the Peru continental margin and adjacent Nazca plate, $9^{\circ} \mathrm{S}$ latitude, in Nazca Plate: Crustal Formation and Andean Convergence, edited by L. D. Kulm et al., Mem. Geol. Soc. Am. 154, 423-443, 1981.

Kanamori, H., Tectonic implications of the 1944 Tonankai and the 1946 Nankaido earthquakes, Phys. Earth Planet. Inter., 5, 129-139, 1972.

Kappel, E., Plate convergence in the Sunda and Banda arcs, B.A. thesis, 40 pp., Comell Univ., Ithaca, N.Y., 1980.

Karig, D., Kinematics and mechanics of deformation across some accreting forearcs in Formation of Accive Ocean Margins, edited by N. Nasu et al., pp. 155-177, Terrapub, Tokyo, 1985.

Karig, D.E., J.G. Caldwell, and E.M. Parmentier, Effects of accretion on the geometry of the descending lithosphere, J. Geophys. Res., $81,6281-6291,1976$.

Kawamura, T., and Y. Aoki, The Nankai Trough margin, record 55-8 in Seismic Images of Modem Convergent Margins Tectonic Structure, edited by R. von Huene, AAPG Stud. Geol. 26, 54-56, 1986.

Keller, G., Benthic foraminifers and paleobathymetry of the Japan trench area, Leg 57, Deep Sea Drilling Project, Initial Rep. Deep Sea Drill. Proj., 56-57, part 2, 835-865, 1980.

Kieckhefer, R.M., G. F. Moore, and F.J. Emmel, Crustal structure of the Sunda Forearc region west of Central Sumatra from gravity data, $J$. Geophys. Res., 86, 7003-7012, 1981.

Kimura, G., S. Miyashita and S. Miyasaka, Collision tectonics in Hokkaido and Sakhalin, in Accretion Teclonics in the Circum Pacific Regions, edited by M. Hashimolo and S. Uyeda, Pp. 117 128, Terrapub, Tokyo, 1983.

Komatsu, M., S. Miyashita, J.J. Maeda, Y. Osanai, and J. Toyosaima, Disclosing of a deepest section of continental crust upthrust as the final stage event of collision of arcs in Hokkaido, north Japan, in Accretion Tectonics in the Circum Pacific Regions, edited by $M$. Hashimoto and S. Uyeda, pp. 117-128, Terrapub, Tokyo, 1983.

Konda, T., and Y. Uyeda, K-Ar age of the tertiary volcanic rocks in the Tohoku area, J. Jpn. Assoc. Mineral. Petrol. Econ. Geol., 2, 343$346,1980$.

Kroenke, L.W., C. Jouannic, and P. Woodward, Bathymetry of the Southwest Pacific, CCOP-SOPAC, 1st edition, scale: 1:6,440,000, 1983.

Kulm, L.D., et al., Western North American continental margin and adjacent ocean floor off Oregon and Washington, Allas 1, 32 sheets, Ocean Drill. Program Reg. Atlas ser. Mar. Sci. Int., Woods Hole, Mass., 1984.

Ladd, J.W. and R.T. Buffler (Eds.), Middle America Trench off Western Central America, Atlas 7, 21 sheets, Ocean Drill. Program Reg. Atlas ser. Mar. Sci. Int., Woods Hole, Mass., 1985.

Lallemand, S., and N. Chamot-Rooke, Sur la cause du décrochement senestre entre les fosses du Japon el des Kouriles: subductioncollision d'un ancien volcan sous-marin (in French with English abstract), C. R. Acad. Sci. Paris ser. 2, 303, 1443-1448, 1986. 
Lallemand, S., and L. Jolivet, Japan Sea: a pull-apart basin?, Earth Planet. Sci. Lett., 76, 375-389, 1985.

Lallemand, S., and X. Le Pichon, Coulomb wedge model applied to subduction of seamounts in the Japan Trench, Geology, 15, 10651069, 1987.

Lallemand, S., R. von Huene, and R. Culotta, Subduction of the Daiichi Kashima seamount in the Japan irench, Tectonophysics, 160, 231$247,1989$.

Lallemand, S., J.-Y. Collot, B. Pelletier, C. Rangin, and J.-P. Cadet, Impact of oceanic asperities on the tectogenesis of modern convergent margins, Oceanol. Acta, spec. vol. 10, 17-30, 1990.

Langmuir, C. H., H. Bougault, J. R. Delanay, H. J. B. Dick, C. Hawkesworth, A. W. Hofman, R. Kay, K. C. McDonald, J. Malpas, and W. J. Morgan, Mantle-crust interactions, paper presented at Second Conference on Scientific Ocean Drilling "Cosod II", European Science Foundation, Strasbourg, 6-8 July 1987.

Langseth, M.G., R. von Huene, N. Nasu, and H. Okada, Subsidence of the Japan Trench forearc region of northem Honshu, Oceanol. Acta, Proceedings 26th International Geological Congress, Geology of Continental Margins Symposium, Paris, July 7-17, 1980.

Leg 127 Scientific Party, Les premiers forages de la croûte océanique de la Mer du Japon; résultats préliminaires du Leg ODP 127, C. R. Acad. Sci. Paris, 311, 837-844, 1990.

Lehner, P., H. Doust, G. Bakker, P. Allenbach and J. Gueneau, Japan Trench, Profile P-849, in Seismic Expression of Structural Styles -A Picture and Work Atlas, edited by A.W. Bally, AAPG stud. Geol. 15, 3.4.2-2, 1983.

Le Pichon X., T. Iiyama, H. Chamley, J. Charvet, M. Faure, H. Fujimoto, T. Furuta, Y. Ida, H. Kagami, S. Lallemant, J. Leggen, A. Murata, H. Okada, C. Rangin, V. Renard, A. Taira, and H. Tokuyama, Nankai trough and the fossil Shikoku Ridge: results of Box 6 KAIKO Survey, Earth Planet. Sci. Lett., 83, 186-198, 1987.

Lewis, S.D., and D.E. Hayes, A geophysical study of the Manila trench, Luzon, Philippines, 2, Fore Arc basin structural and stratigraphic evolution, J. Geophys. Res., 89, 9196-9214, 1984.

Lonsdale, P., Paleogene history of the Kula plate: Offshore evidence and onshore implications, Geol. Soc. Am. Bull., 733-754, 1988.

Ludwig, WJ., J.I. Ewing, M. Ewing, S. Murauchi, N. Den, S. Asano, H. Hotta, M. Hayakawa, T. Asanuma, K. Ichikawa, and I. Noguchi, Sediments and structure of the Japan trench, J. Geophys. Res., 71, 2121-2137, 1966.

Mc Adoo, D.C., et al., On the elastic-perfectly plastic bending of the lithosphere under generalized loading with application to the Kuril Trench, Geophys. J. R. Astron. Soc., 54, 11-26, 1978.

McCaffrey, R., Active tectonics of the eastem Sunda and Banda arcs, $J$. Geophys. Res., 93, 15163-15182, 1988.

McCaffrey, R., and J. Nabelek, Earthquakes, gravity, and the origin of the Bali Basin: An example of a nascent continental fold-and-thrust belt, J. Geophys. Res., 92, 441-460, 1987.

Mammerickx, J., and S.M. Smith, Bathymetry of the southeast Pacific, scale 1:6,440,000, Scripps Institution of Oceanography, 1978.

Maritime Safety Agency, Bathymetric Chart of north-east Nippon, $n^{\circ}$ 6312, scale 1:1,000,000, Tokyo, Japan, 1983a.

Maritime Safety Agency, Bathymetric Chart of south-west Nippon, $\mathrm{n}^{\circ}$ 6314, scale 1:1,000,000, Tokyo, Japan, $1983 b$.

Maritime Safety Agency, Bathymetric Chan of Hokkaido, $n^{\circ} 6311$. scale 1:1,000,000. Tokyo, Japan, 1983c.

Michaelson, C.A., and C.S. Weaver, Upper mantle structure from teleseismic $P$ wave arrivals in Washington and nothern Oregon, $J$. Geophys. Res., 91, 2077-2094, 1986.

Missègue, F., and A. Malahoff, Elude gravimétrique de l'arc des Tonga, in Contribution à l'étude géodynamique du Sud-Ouest Pacifique (in French), Trav. Doc. ORSTOM 147, 293-298, 1982.

Mizoue, M., M. Nakamura, N. Seto, and Y. Ishiketa, Three-layered distribution of microearthquakes in relation to focal mechanism variation in the Kii Peninsula, Southwestem Honshu, Japan, Bull. Earthquake Res. Inst. Univ. Tokyo, 58, 287-310, 1983.

Molnar, P., D. Freedman, and J. Shih, Lengths of intermediate and deep seismic zones and temperatures in downgoing slabs of lithosphere, Geophys. J. R. Astron. Soc., 56, 41-54, 1979.

Moore, G.W., and K. Fujioka, Age and origin of dacite boulder conglomerate anomalously near the Japan Trench, Initial Rep. Deep Sea Drill. Proj., 56-57, part 2, 1083-1088, 1980.

Murauchi, S., and W.J. Ludwig, Crustal structure of the Japan Trench: The effect of subduction of ocean crust, legs 56-57, Initial Rep. Deep Sea Drill. Proj., 56-57, pant 1, 463-469, 1980.
Murauchi, S., N. Den, S. Asano, Hotta, J. Chujo, T. Asanuma, K. Ichikawa and I. Noguchi, A seismic refraction exploration of Kumanonada, Japan, Proc. Jpn. Acad. Sci., 40, 11, 1964.

Murauchi, S., N. Den, S. Asano, H. Hotta, T. Yoshii, T. Asanuma, K. Hagiwara, K. Ichikawa, T. Sato, W.J. Ludwig, J.I. Ewing, N.T. Edgar, and R.E. Houtz, Crustal structure of the Philippine Sea, $J$. Geophys. Res., 73, 3143-3171, 1968.

Murauchi, S., T. Asanuma, H. Taguchi, H. Kinoshita, I. Yokoyama, H. Nakatani, T. Yokota, and K. Tanaka, Crustal structure of the islandarc slope and the trench off Sanriku and mechanism of subduction (in Japanese), Mar. Sci., 10, 207-214, 1978.

Nagao, T., and S. Uyeda, Heat-flow measurements in the northern part of Honshu, Northeast Japan, using shallow holes, Tectonophysics, $164,301-314,1989$.

Nagumo, S., J. Kasahara, and S. Koresawa, OBS airgun seismic refraction survey near sites 441 and 434 (J-1A), 438 and 439 (J-12), and proposed site J-2B: Legs 56 and 57, DSDP, Initial Rep. Deep Sea Drill. Proj., 56-57, part 1, 459-462, 1980.

Nakanishi, I., Precursors to ScS phases and dipping interface in the upper mantle beneath southwestern Japan, Tectonophysics, 69, 1$35,1980$.

Nakanishi, M., K. Tamaki, and K. Kobayashi, Mesozoic magnetic anomaly lineations and seafloor spreading history of the northwestern Pacific, J. Geophys. Res., 94, 15437-15462, 1989.

Nasu, N., R. von Huene, Y. Ishiwada, M. Langseth, T. Bruns, and E. Honza, Interpretation of multichannel seismic reflection data, legs 56 and 57, Japan Trench transect, Deep Sea Drilling Project, Initial Rep. Deep Sea Drill. Proj., 56-57, part 1, 489-504, 1980.

Nishizawa, A., and K. Suyehiro, Crustal structure across the Kurile trench off south-eastern Hokkaido by airgun-OBS profiling, Geophys. J. R. Astron. Soc., 86, 371-397, 1986.

Oda, H., T. Tanaka, and K. Seya, Subducting oceanic crust on the Philippine Sea Plate in Southwest Japan, Tectonophysics, 172, 175-189, 1990.

Ohguchi, T., T. Yoshida, and K. Okami, Historical change of the Neogene and Quatemary volcanic field in the northeast Honshu arc, Mem. Geol. Soc. Jpn., 32, 431-455, 1989.

Okada, H., S. Asano, T. Yoshii, A. Ikami, S. Suzuki, T. Hasegawa, K. Yamamoto, K. Ito, and K. Hamada, Regionality of the upper mantle around northeastem Japan as revealed by big explosions at sea, 1 . SEIHA-1 explosion experiment, J. Phys. Earth, 27, 15-32, 1979.

Pardo-Casas, F., and P. Molnar, Relative motion of the Nazca (Farallon) and south American plates since late Cretaceous time, Tectonics, 6, 233-248, 1987.

Pautot, G., and C. Rangin, Subduction of the South China Sea axial ridge below Luzon (Philippines), Earth Planet. Sci. Lett., 92, 57-69. 1989.

Pelletier, B., and J. Dupont, Effets de la subduction de la ride de Louisville sur l'arc des Tonga-Kermadec, Oceanol. Acta, spec. vol. 10, 57-76, 1990.

Pelletier, B., and R. Louat, Seismotectonics and present-day relative plate motions in the Tonga-Lau and Kermadec-Havre region, Tectonophysics, 165, 237-250, 1989.

Pennington W.D., The effect of oceanic crustal structure on phase changes and subduction, Tectonophysics, 102, 377-398, 1984.

Pontoise B. and G. Latham, Etude par réfraction de la stnucture inteme de l'arc des Tonga, in: "Contribulion à l'étude géodynamique du sudouest Pacifique". Travaux et documents de l'ORSTOM, $n^{\circ} 147,283-$ $292,1982$.

Rangin, C., and M. Pubellier, Subduction and accretion of Philippine Sea Plate fragments along the Eurasian margin in Tectonics of Circum-Pacific Continental Margins, edited by J. Aubouin and J. Bourgois, VSP, 139-164, 1990.

Ranken, B., R.K. Cardwell, and D.E. Karig, Kinematics of the Philippine Sea plate, Tectonics, 3, 555-575, 1984.

Reyners, M., A microearthquake study of the plate boundary, North Island, New Zealand, Geophys. J. R. Astron. Soc., 63, 1-22, 1980.

Richter, F.M., Focal mechanisms and seismic energy release of deep and intermediate earthquakes in the Tonga-Kermadec region and their bearing on the depth extend of mantle flow, J. Geophys. Res., 84, 6783-6795, 1979.

Ruff, L., and H. Kanamori , Seismic coupling and uncoupling at subduction zones, Teclonophysics, 99, 99-117, 1983.

Rutland, R.W.R., Andean orogeny and ocean floor spreading, Nature, 233, 252-255, 1971.

Sakurai, M., A. Mogi, J. Chujo, and T. Miyazaki, Multichannel 
seismic reflection profiling off Joban District Northeast Japan, Rep. Hydrogr. Res., 16, 1-17, 1981.

Scholl, D.W., R. von Huene, T. L. Vallier, and D.G. Howell, Sedimentary masses and concepts about tectonic processes at underthrust ocean margins, Geology, 8, 564-568, 1980.

Scholl, D.W., J. McCarthy, and H. Ryan, Forearc margin, Central Aleoutian Ridge, in Seismic Images of Modem Convergent Margins Tectonic Structure, edited by R. von Huene, AAPG Stud. Geol. 26, 10-13, 1986.

Seno, T., The instantaneous rotation vector of the Philippine Sea plate relative to the Eurasian plate, Tectonophysics, 42, 209-226, 1977.

Seno, T., Is Northem Honshu a microplate?, Tectonphysics, 115, 177 196, 1985.

Shiki, T., and Y. Miyake, Continental slope structural high igneous activity and its bearing on the geotectonic history of the Philippine Sea, J. Phys. Earth, 36, 143-155, 1988.

Shipley, T.H., and G.F. Moore, Sediment accretion, subduction, and dewatering at the base of the trench slope off Costa Rica: A seismic reflection view of the décollement, J. Geophys. Res., 91, 2019$2028,1986$.

Sleep, N.H., The double seismic zone in downgoing slabs and the viscosity of mesosphere, J. Geophys. Res., 84, 4565-4571, 1979.

Speed, R.C., et al., Lesser Antilles Arc and adjacent terranes, Ocean Drill. Program Reg. Atlas Ser., Atlas 10, 27 sheets, Mar. Sci. Int., Woods Hole, Mass., 1984.

Spence, W., The 1977 Sumba earthquake series: Evidence for slab pull force acting at a subduction zone, J. Geophys. Res., 91, 7225-7239. 1986.

Spence, W., Slab pull and seismotectonics of subducting lithosphere, Reviews of Geophysics, 25, 55-69, 1987.

Spence, W., Stress origins and earthquake potentials in Cascadia, $J$. Geophys. Res., 94, 3076-3088, 1989.

Taber, J.J., and S.W. Smith, Seismicity and focal mechanisms associated with the subduction of the Juan de Fuca plate beneath the Olympic peninsula, Washington, Bull. Seismol. Soc. Am., 75, 237249. 1985.

Takigami, Y., and K. Fujioka, ${ }^{40} \mathrm{Ar} /{ }^{39}$ Ar dating of homfels near the Japan Trench, Bull. Volcanol. Soc. Jpn., 34, 181-188, 1989.

Tamaki, K., et al., Proc. Ocean Drill. Program, Initial Rep., 127, 1990.

Tsuchi, R. (Ed.), Fundamental data on Japanese Neogene bio- and chronostratigraphy, IGCP-114, National working Group of Japan, 1979.

Tsunakawa, H., Neogene stress field of the japanese arcs and its relation to igneous activity, Tectonophysics, 124, 1-22, 1986.

von Huene, R., Tectonic processes along the front of modem convergent margins - Research of the past decade, Annu. Rev. Earth Planet. Sci., 12, 359-381, 1984a.

von Huene, R., Structural diversities along modem convergent margins and the role of overpressured pore fluids in subduction zones, $B$ ull. Soc. Geol. Fr., 7, 2, 207-219, $1984 b$.

von Huene, R., Some implications regarding tectonic mechanisms from the structural diversity along several modem convergent margins, in Formation of Aclive Ocean Margins, edited by N. Nasu et al., pp. 179-191, Terrapub, Tokyo, 1985. von Huene, R., et al., Results of Leg 112 drilling, Peru continental margin: Part 1, tectonic history, Geology, 16, 934-938, 1989.

von Huene, R., and R. Culotta, Tectonic erosion at the front of the Japan Trench convergent margin, Tectonophysics, 160, 75-90, 1989.

von Huene, R., and S. Lallemand, Tectonic erosion along the Japan and Peru convergent margins, Geol. Soc. Am. Bull., 102, 704-720, 1990.

von Huene, R., and D.W. Scholl, Observations at convergent margins concerning sediment subduction, subduction erosion, and the growth of continental crust, Rev. Geophys., 29, 279-316, 1991.

von Huene, R., M. Langseth, N. Nasu, and H. Okada, Summary, Japan Trench transect, leg 56-57, Initial Rep. Deep Sea Drill. Proj., 56 57. part 1, 473-488, 1980.

von Huene, R., M. Langseth, N. Nasu, and H. Okada, A summary of Cenozoïc tectonic history along the IPOD Japan trench transect, Geol. Soc. Am. Bull., 93, 829-846, 1982.

von Huene, R., L. Kulm, J. Miller, and D. Hussong, The Peru continental margin, record sections 2 and 3, in Seismic Images of Modem Convergent Margins Tectonic Structure, edited by $R$. von Huene, AAPG Stud. Geol. 26, 37-40, 1986.

Wadge, G., and J.B. Shepherd, Segmentation of the Lesser Antilles subduction zone, Earth Planet. Sci. Lett., 71, 297-304, 1984.

Walcott, R.I., Flexure of the lithosphere at Hawaï, Tectonophysics, 9, 435-446, 1970.

Watts, A.B., and M. Talwani, Gravity anomalies seaward of deep-sea trenches and their tectonic implications, Geophys. J. R. Astron. Soc., 36, 57-90, 1974.

Westbrook, G.K., J.W. Ladd, P. Buhl, N. Bangs, and G.J. Tiley, Cross section of an accretionary wedge: Barbados Ridge Complex, Geology, 16, 631-635, 1988.

Wiens, D.A., Bathymetric effects on body waveforms from shallow subduction zone earthquakes and application to seismic processes in the Kurile trench, J. Geophys. Res., 94, 2955-2972, 1989.

Yanagisawa, M., Y. Takigami, M. Ozima, and I. Kaneoka, ${ }^{40} \mathrm{Ar} /{ }^{39} \mathrm{Ar}$ ages of boulders drilled at site 439, Leg 57, Deep Sea Drilling Project, Initial Rep. Deep Sea Drill. Proj., 56-57, part 2, 12811284, 1980.

Yoshii, T., Crust and upper mantle structure beneath northeastem Japan (in Japanese), Kagaku, 47, 170-176, 1977.

Yoshii, T., A detailed cross section of the deep seismic zone beneath northeastem Honshu, Japan, Tectonophysics, 55, 349-360, 1979.

Yoshii, T., W. J. Ludwig, N. Den, S. Murauchi M. Ewing, H. Hotta, P. Buhl. T. Asanuma, and N. Sakajiri, Structure of Southwest Japan Margin off Shikoku, J. Geophys. Res., 78, 2517-2530, 1973.

S. E. Lallemand, P. Schnurle and S. Manoussis, URA CNRS 1315 , Université Pierre et Marie Curie, Laboratoire de Géologie Structurale, Boîte 129, Tour 26-0, E1, 4 place Jussieu, 75252, Paris cédex 05, France.

(Received January 2, 1991;

revised June 12, 1991;

accepted September 12, 1991.) 